\title{
Adenosine receptors in GtoPdb v.2021.2
}

Bertil B. Fredholm ${ }^{1}$, Bruno G. Frenguelli ${ }^{2}$, Rebecca Hills ${ }^{3}$, Adriaan P. IJzerman ${ }^{4}$, Kenneth A. Jacobson $^{5}$, Karl-Norbert Klotz ${ }^{6}$, Joel Linden ${ }^{7}$, Christa E. Müller ${ }^{8}$, Ulrich Schwabe ${ }^{9}$ and Gary L. Stiles ${ }^{10}$

1. Karolinska Institutet, Sweden

2. University of Warwick, UK

3. University of Edinburgh, UK

4. Leiden University, The Netherlands

5. National Institutes of Health, USA

6. Universität Würzburg, Germany

7. La Jolla Institute for Allergy and Immunology, USA

8. Universität Bonn, Germany

9. Pharmakologisches Institut der Universität Heidelberg, Germany

10. Duke University, USA

\begin{abstract}
Adenosine receptors (nomenclature as agreed by the NC-IUPHAR Subcommittee on

Adenosine Receptors [110]) are activated by the endogenous ligand adenosine (potentially inosine also at $A_{3}$ receptors). Crystal structure for the antagonist-bound [153, 313, 221, 61], agonist-bound $[375,203,204]$ and $G$ protein-bound $A_{2 A}$ adenosine receptors [49] have been described. The structures of an antagonist-bound $A_{1}$ receptor [128] and an adenosine-bound $A_{1}$ receptor- $G_{i}$ complex [86] have been resolved by cryo-electronmicroscopy. Another structure of an antagonist-bound $A_{1}$ receptor obtained with X-ray crystallography has also been reported [57]. caffeine is a nonselective antagonist for adenosine receptors, while istradefylline, a selective $\mathrm{A}_{2 \mathrm{~A}}$ receptor antagonist, is on the market for the treatment of Parkinson's disease.
\end{abstract}

\section{Contents}

This is a citation summary for Adenosine receptors in the Guide to Pharmacology database (GtoPdb). It exists purely as an adjunct to the database to facilitate the recognition of citations to and from the database by citation analyzers. Readers will almost certainly want to visit the relevant sections of the database which are given here under database links.

GtoPdb is an expert-driven guide to pharmacological targets and the substances that act on them. GtoPdb is a reference work which is most usefully represented as an on-line database. As in any publication this work should be appropriately cited, and the papers it cites should also be recognized. This document provides a citation for the relevant parts of the database, and also provides a reference list for the research cited by those parts. For further details see [45].

Please note that the database version for the citations given in GtoPdb are to the most recent preceding version in which the family or its subfamilies and targets were substantially changed. The links below are to the current version. If you need to consult the cited version, rather than the most recent version, please contact the GtoPdb curators.

\section{Database links}

Adenosine receptors

https://www.guidetopharmacology.org/GRAC/FamilyDisplayForward?familyId=3

Introduction to Adenosine receptors

https://www.guidetopharmacology.org/GRAC/FamilyIntroductionForward?familyId=3

Receptors

$\mathrm{A}_{1}$ receptor 
https://www.guidetopharmacology.org/GRAC/ObjectDisplayForward?objectId=18 $\mathrm{A}_{2 \mathrm{~A}}$ receptor

https://www.guidetopharmacology.org/GRAC/ObjectDisplayForward?objectId=19 $\mathrm{A}_{2 \mathrm{~B}}$ receptor

https://www.guidetopharmacology.org/GRAC/ObjectDisplayForward?objectId=20 $\mathrm{A}_{3}$ receptor

https://www.guidetopharmacology.org/GRAC/ObjectDisplayForward?objectId=21

\section{References}

1. Abo-Salem OM, Hayallah AM, Bilkei-Gorzo A, Filipek B, Zimmer A and Müller CE. (2004) Antinociceptive effects of novel A2B adenosine receptor antagonists. J Pharmacol Exp Ther 308: 358-66 [PMID:14563788]

2. Adams JL, Smothers J, Srinivasan R and Hoos A. (2015) Big opportunities for small molecules in immuno-oncology. Nat Rev Drug Discov 14: 603-22 [PMID:26228631]

3. Adén U, Halldner L, Lagercrantz H, Dalmau I, Ledent C and Fredholm BB. (2003) Aggravated brain damage after hypoxic ischemia in immature adenosine A2A knockout mice. Stroke 34: 739-44 [PMID:12624301]

4. Albrecht-Küpper BE, Leineweber K and Nell PG. (2012) Partial adenosine A1 receptor agonists for cardiovascular therapies. Purinergic Signal 8: 91-9 [PMID:22081230]

5. Alexander SP, Cooper J, Shine J and Hill SJ. (1996) Characterization of the human brain putative A2B adenosine receptor expressed in Chinese hamster ovary (CHO.A2B4) cells. Br J Pharmacol 119: 1286-90 [PMID:8937736]

6. Alexander SP and Millns PJ. (2001) [(3)H]ZM241385--an antagonist radioligand for adenosine A(2A) receptors in rat brain. Eur J Pharmacol 411: 205-10 [PMID:11164377]

7. Ali RA, Gandhi AA, Meng H, Yalavarthi S, Vreede AP, Estes SK, Palmer OR, Bockenstedt PL, Pinsky DJ and Greve JM et al.. (2019) Adenosine receptor agonism protects against NETosis and thrombosis in antiphospholipid syndrome. Nat Commun 10: 1916 [PMID:31015489]

8. Allegrucci C, Liguori L and Minelli A. (2001) Stimulation by n6-cyclopentyladenosine of A1 adenosine receptors, coupled to galphai2 protein subunit, has a capacitative effect on human spermatozoa. Biol Reprod 64: 1653-9 [PMID:11369591]

9. Anderson R, Sheehan MJ and Strong P. (1994) Characterization of the adenosine receptors mediating hypothermia in the conscious mouse. Br J Pharmacol 113: 1386-90 [PMID:7889296]

10. Arizmendi $\mathrm{N}$ and Kulka M. (2018) Adenosine activates $\mathrm{G} \alpha_{\mathrm{s}}$ proteins and inhibits C3a-induced activation of human mast cells. Biochem Pharmacol 156: 157-167 [PMID:30099007]

11. Arrigoni E, Crocker AJ, Saper CB, Greene RW and Scammell TE. (2005) Deletion of presynaptic adenosine A1 receptors impairs the recovery of synaptic transmission after hypoxia. Neuroscience 132: 575-80 [PMID:15837119]

12. Arslan G, Kull B and Fredholm BB. (1999) Signaling via A2A adenosine receptor in four PC12 cell clones. Naunyn Schmiedebergs Arch Pharmacol 359: 28-32 [PMID:9933147]

13. Atkinson MR, Townsend-Nicholson A, Nicholl JK, Sutherland GR and Schofield PR. (1997) Cloning, characterisation and chromosomal assignment of the human adenosine A3 receptor (ADORA3) gene. Neurosci Res 29: 73-79 [PMID:9293494]

14. Auchampach JA, Jin X, Wan TC, Caughey GH and Linden J. (1997) Canine mast cell adenosine receptors: cloning and expression of the $\mathrm{A} 3$ receptor and evidence that degranulation is mediated by the A2B receptor. Mol Pharmacol 52: 846-60 [PMID:9351976]

15. Auchampach JA, Kreckler LM, Wan TC, Maas JE, van der Hoeven D, Gizewski E, Narayanan J and Maas GE. (2009) Characterization of the A2B adenosine receptor from mouse, rabbit, and dog. J Pharmacol Exp Ther 329: 2-13 [PMID:19141710]

16. Aurelio L, Valant C, Flynn BL, Sexton PM, Christopoulos A and Scammells PJ. (2009) Allosteric modulators of the adenosine A1 receptor: synthesis and pharmacological evaluation of 4substituted 2-amino-3-benzoylthiophenes. J Med Chem 52: 4543-7 [PMID:19514747]

17. Avila MY, Stone RA and Civan MM. (2002) Knockout of A3 adenosine receptors reduces mouse intraocular pressure. Invest Ophthalmol Vis Sci 43: 3021-6 [PMID:12202525]

18. Baraldi PG, Cacciari B, Romagnoli R, Merighi S, Varani K, Borea PA and Spalluto G. (2000) A(3) adenosine receptor ligands: history and perspectives. Med Res Rev 20: 103-28 [PMID:10723024]

19. Baraldi PG, Cacciari B, Romagnoli R, Varani K, Merighi S, Gessi S, Borea PA, Leung E, Hickey SL and Spalluto G. (2000) Synthesis and preliminary biological evaluation of [3H]-MRE 3008F20: the first high affinity radioligand antagonist for the human A3 adenosine receptors. Bioorg Med Chem Lett 10: 209-11 [PMID:10698437]

20. Baraldi PG, Cacciari B, Spalluto G, Ji XD, Olah ME, Stiles G, Dionisotti S, Zocchi C, Ongini E and Jacobson KA. (1996) Novel N6-(substituted-phenylcarbamoyl)adenosine-5'-uronamides as potent agonists for A3 adenosine receptors. J Med Chem 39: 802-6 [PMID:8576924] 
21. Baraldi PG, Tabrizi MA, Preti D, Bovero A, Romagnoli R, Fruttarolo F, Zaid NA, Moorman AR, Varani K and Gessi S et al.. (2004) Design, synthesis, and biological evaluation of new 8heterocyclic xanthine derivatives as highly potent and selective human A2B adenosine receptor antagonists. J Med Chem 47: 1434-47 [PMID:14998332]

22. Beatty J, Debien L, Jeffery J, Leleti MR, Mandal D, Miles D, Powers J, Rosen B, Thomas_tran R and Sharif E. (2018) AZOLOPYRIMIDINE FOR THE TREATMENT OF CANCER-RELATED DISORDERS Patent number: WO2018136700.

23. Bennett KA, Tehan B, Lebon G, Tate CG, Weir M, Marshall FH and Langmead CJ. (2013) Pharmacology and structure of isolated conformations of the adenosine $\mathrm{A}_{2} \mathrm{~A}$ receptor define ligand efficacy. Mol Pharmacol 83: 949-58 [PMID:23429888]

24. Bertarelli DC, Diekmann M, Hayallah AM, Rüsing D, Iqbal J, Preiss B, Verspohl EJ and Müller CE. (2006) Characterization of human and rodent native and recombinant adenosine $\mathrm{A}(2 \mathrm{~B})$ receptors by radioligand binding studies. Purinergic Signal 2: 559-71 [PMID:18404493]

25. Betti M, Catarzi D, Varano F, Falsini M, Varani K, Vincenzi F, Pasquini S, di Cesare Mannelli L, Ghelardini C and Lucarini E et al.. (2019) Modifications on the Amino-3,5-dicyanopyridine Core To Obtain Multifaceted Adenosine Receptor Ligands with Antineuropathic Activity.J Med Chem 62: 6894-6912 [PMID:31306001]

26. Beukers MW, Chang LC, von Frijtag Drabbe Künzel JK, Mulder-Krieger T, Spanjersberg RF, Brussee J and IJzerman AP. (2004) New, non-adenosine, high-potency agonists for the human adenosine A2B receptor with an improved selectivity profile compared to the reference agonist N-ethylcarboxamidoadenosine. J Med Chem 47: 3707-9 [PMID:15239649]

27. Beukers MW, den Dulk H, van Tilburg EW, Brouwer J and Ijzerman AP. (2000) Why are A(2B) receptors low-affinity adenosine receptors? Mutation of Asn273 to Tyr increases affinity of human A(2B) receptor for 2-(1-Hexynyl)adenosine. Mol Pharmacol 58: 1349-56 [PMID:11093773]

28. Beukers MW, Klaassen CH, De Grip WJ, Verzijl D, Timmerman H and Leurs R. (1997) Heterologous expression of rat epitope-tagged histamine $\mathrm{H} 2$ receptors in insect Sf9 cells. $\mathrm{Br} \mathrm{J}$ Pharmacol 122: 867-74 [PMID:9384502]

29. Beukers MW, Wanner MJ, Von Frijtag Drabbe Künzel JK, Klaasse EC, IJzerman AP and Koomen GJ. (2003) N6-cyclopentyl-2-(3-phenylaminocarbonyltriazene-1-yl)adenosine (TCPA), a very selective agonist with high affinity for the human adenosine A1 receptor. J Med Chem 46: 1492503 [PMID:12672250]

30. Beuming T and Sherman W. (2012) Current assessment of docking into GPCR crystal structures and homology models: successes, challenges, and guidelines. J Chem Inf Model 52: 3263-77 [PMID:23121495]

31. Bhattacharya S and Linden J. (1995) The allosteric enhancer, PD 81,723, stabilizes human A1 adenosine receptor coupling to G proteins. Biochim Biophys Acta 1265: 15-21 [PMID:7857979]

32. Bjorness TE, Kelly CL, Gao T, Poffenberger V and Greene RW. (2009) Control and function of the homeostatic sleep response by adenosine A1 receptors. J Neurosci 29: 1267-76 [PMID:19193874]

33. Björklund O, Halldner-Henriksson L, Yang J, Eriksson TM, Jacobson MA, Daré E and Fredholm BB. (2008) Decreased behavioral activation following caffeine, amphetamine and darkness in A3 adenosine receptor knock-out mice. Physiol Behav 95: 668-76 [PMID:18930070]

34. Bonizzoni E, Milani S, Ongini E, Casati C and Monopoli A. (1995) Modeling hemodynamic profiles by telemetry in the rat. A study with A1 and A2a adenosine agonists. Hypertension 25 : 564-9 [PMID:7721399]

35. Borodovsky A, Barbon CM, Wang Y, Ye M, Prickett L, Chandra D, Shaw J, Deng N, Sachsenmeier K and Clarke JD et al.. (2020) Small molecule AZD4635 inhibitor of A 2A R signaling rescues immune cell function including CD103 + dendritic cells enhancing anti-tumor immunity $J$ Immunother Cancer 8: e000417 [PMID:32727810]

36. Borrmann T, Hinz S, Bertarelli DC, Li W, Florin NC, Scheiff AB and Müller CE. (2009) 1-alkyl-8(piperazine-1-sulfonyl)phenylxanthines: development and characterization of adenosine A2B receptor antagonists and a new radioligand with subnanomolar affinity and subtype specificity. $J$ Med Chem 52: 3994-4006 [PMID:19569717]

37. Bosch MP, Campos F, Niubó I, Rosell G, Díaz JL, Brea J, Loza MI and Guerrero A. (2004) Synthesis and biological activity of new potential agonists for the human adenosine A2A receptor. J Med Chem 47: 4041-53 [PMID:15267242]

38. Brackett LE and Daly JW. (1994) Functional characterization of the A2b adenosine receptor in NIH 3T3 fibroblasts. Biochem Pharmacol 47: 801-14 [PMID:8135856]

39. Brambilla R, Cattabeni F, Ceruti S, Barbieri D, Franceschi C, Kim YC, Jacobson KA, Klotz KN, Lohse MJ and Abbracchio MP. (2000) Activation of the A3 adenosine receptor affects cell cycle progression and cell growth. Naunyn Schmiedebergs Arch Pharmacol 361: 225-34 [PMID:10731034]

40. Briddon SJ, Middleton RJ, Cordeaux Y, Flavin FM, Weinstein JA, George MW, Kellam B and Hill SJ. (2004) Quantitative analysis of the formation and diffusion of A1-adenosine receptorantagonist complexes in single living cells. Proc Natl Acad Sci USA 101: 4673-8 
[PMID:15070776]

41. Brown R, Ollerstam A, Johansson B, Skøtt O, Gebre-Medhin S, Fredholm B and Persson AE. (2001) Abolished tubuloglomerular feedback and increased plasma renin in adenosine A1 receptor-deficient mice. Am J Physiol Regul Integr Comp Physiol 281: R1362-7 [PMID:11641103]

42. Bruns RF. (1980) Adenosine receptor activation in human fibroblasts: nucleoside agonists and antagonists. Can J Physiol Pharmacol 58: 673-91 [PMID:6253037]

43. Bruns RF and Fergus JH. (1990) Allosteric enhancement of adenosine A1 receptor binding and function by 2-amino-3-benzoylthiophenes. Mol Pharmacol 38: 939-49 [PMID:2174510]

44. Bruns RF, Fergus JH, Coughenour LL, Courtland GG, Pugsley TA, Dodd JH and Tinney FJ. (1990) Structure-activity relationships for enhancement of adenosine A1 receptor binding by 2-amino-3benzoylthiophenes. Mol Pharmacol 38: 950-8 [PMID:2250667]

45. Buneman P, Christie G, Davies JA, Dimitrellou R, Harding SD, Pawson AJ, Sharman JL and Wu Y. (2020) Why data citation isn't working, and what to do about it Database $\mathbf{2 0 2 0}$ [PMID:32367113]

46. Børglum JD, Vassaux G, Richelsen B, Gaillard D, Darimont C, Ailhaud G and Négrel R. (1996) Changes in adenosine A1- and A2-receptor expression during adipose cell differentiation. Mol Cell Endocrinol 117: 17-25 [PMID:8734470]

47. Cagnina RE, Ramos SI, Marshall MA, Wang G, Frazier CR and Linden J. (2009) Adenosine A2B receptors are highly expressed on murine type II alveolar epithelial cells. Am J Physiol Lung Cell Mol Physiol 297: L467-74 [PMID:19574419]

48. Carlsson J, Yoo L, Gao ZG, Irwin JJ, Shoichet BK and Jacobson KA. (2010) Structure-based discovery of A2A adenosine receptor ligands. J Med Chem 53: 3748-55 [PMID:20405927]

49. Carpenter B, Nehmé R, Warne T, Leslie AG and Tate CG. (2016) Structure of the adenosine $\mathrm{A}(2 \mathrm{~A})$ receptor bound to an engineered G protein. Nature 536: 104-7 [PMID:27462812]

50. Carroll MA, Doumad AB, Li J, Cheng MK, Falck JR and McGiff JC. (2006) Adenosine2A receptor vasodilation of rat preglomerular microvessels is mediated by EETs that activate the cAMP/PKA pathway. Am J Physiol Renal Physiol 291: F155-61 [PMID:16478979]

51. Cerniway RJ, Yang Z, Jacobson MA, Linden J and Matherne GP. (2001) Targeted deletion of A(3) adenosine receptors improves tolerance to ischemia-reperfusion injury in mouse myocardium. Am J Physiol Heart Circ Physiol 281: H1751-8 [PMID:11557567]

52. Chang LC, von Frijtag Drabbe Künzel JK, Mulder-Krieger T, Westerhout J, Spangenberg T, Brussee J and Ijzerman AP. (2007) 2,6,8-trisubstituted 1-deazapurines as adenosine receptor antagonists. J Med Chem 50: 828-34 [PMID:17300165]

53. Chen JF. (2003) The adenosine A(2A) receptor as an attractive target for Parkinson's disease treatment. Drug News Perspect 16: 597-604 [PMID:14702141]

54. Chen JF, Beilstein M, Xu YH, Turner TJ, Moratalla R, Standaert DG, Aloyo VJ, Fink JS and Schwarzschild MA. (2000) Selective attenuation of psychostimulant-induced behavioral responses in mice lacking A(2A) adenosine receptors. Neuroscience 97: 195-204 [PMID:10771351]

55. Chen JF, Huang Z, Ma J, Zhu J, Moratalla R, Standaert D, Moskowitz MA, Fink JS and Schwarzschild MA. (1999) A(2A) adenosine receptor deficiency attenuates brain injury induced by transient focal ischemia in mice. J Neurosci 19: 9192-200 [PMID:10531422]

56. Chen Y, Corriden R, Inoue Y, Yip L, Hashiguchi N, Zinkernagel A, Nizet V, Insel PA and Junger WG. (2006) ATP release guides neutrophil chemotaxis via P2Y2 and A3 receptors. Science 314: 1792-5 [PMID:17170310]

57. Cheng RKY, Segala E, Robertson N, Deflorian F, Doré AS, Errey JC, Fiez-Vandal C, Marshall FH and Cooke RM. (2017) Structures of Human A1 and A2A Adenosine Receptors with Xanthines Reveal Determinants of Selectivity. Structure 25: 1275-1285.e4 [PMID:28712806]

58. Christofi FL, Zhang H, Yu JG, Guzman J, Xue J, Kim M, Wang YZ and Cooke HJ. (2001) Differential gene expression of adenosine A1, A2a, A2b, and A3 receptors in the human enteric nervous system. J Comp Neurol 439: 46-64 [PMID:11579381]

59. Chu YY, Tu KH, Lee YC, Kuo ZJ, Lai HL and Chern Y. (1996) Characterization of the rat A2a adenosine receptor gene. DNA Cell Biol 15: 329-37 [PMID:8639269]

60. Coney AM and Marshall JM. (1998) Role of adenosine and its receptors in the vasodilatation induced in the cerebral cortex of the rat by systemic hypoxia. J Physiol (Lond.) 509 ( Pt 2): 507 18 [PMID:9575299]

61. Congreve M, Andrews SP, Doré AS, Hollenstein K, Hurrell E, Langmead CJ, Mason JS, Ng IW, Tehan B and Zhukov A et al.. (2012) Discovery of 1,2,4-triazine derivatives as adenosine A(2A) antagonists using structure based drug design. J Med Chem 55: 1898-903 [PMID:22220592]

62. Cooper JA, Hill SJ, Alexander SP, Rubin PC and Horn EH. (1995) Adenosine receptor-induced cyclic AMP generation and inhibition of 5-hydroxytryptamine release in human platelets. $\mathrm{Br} \mathrm{J}$ Clin Pharmacol 40: 43-50 [PMID:8527267]

63. Cordeaux Y, Ijzerman AP and Hill SJ. (2004) Coupling of the human A1 adenosine receptor to different heterotrimeric $\mathrm{G}$ proteins: evidence for agonist-specific $\mathrm{G}$ protein activation. $\mathrm{Br} \mathrm{J}$ 
Pharmacol 143: 705-14 [PMID:15302686]

64. Cornfield LJ, Hu S, Hurt SD and Sills MA. (1992) [3H]2-phenylaminoadenosine ([3H]CV 1808) labels a novel adenosine receptor in rat brain. J Pharmacol Exp Ther 263: 552-61 [PMID:1331404]

65. Corsi C, Melani A, Bianchi L, Pepeu G and Pedata F. (1999) Striatal A2A adenosine receptors differentially regulate spontaneous and $\mathrm{K}+$-evoked glutamate release in vivo in young and aged rats. Neuroreport 10: 687-691 [PMID:10208531]

66. Costenla AR, Lopes LV, de Mendonça A and Ribeiro JA. (2001) A functional role for adenosine A3 receptors: modulation of synaptic plasticity in the rat hippocampus. Neurosci Lett 302: 53-7 [PMID:11278110]

67. Crawford M, Ford S, Henry M, Matherne GP and Lankford A. (2005) Myocardial function following cold ischemic storage is improved by cardiac-specific overexpression of A1-adenosine receptors. Can J Physiol Pharmacol 83: 493-8 [PMID:16049549]

68. Cunha RA, Johansson B, Constantino MD, Sebastião AM and Fredholm BB. (1996) Evidence for high-affinity binding sites for the adenosine A2A receptor agonist [3H] CGS 21680 in the rat hippocampus and cerebral cortex that are different from striatal A2A receptors. Naunyn Schmiedebergs Arch Pharmacol 353: 261-71 [PMID:8692280]

69. Dalpiaz A, Townsend-Nicholson A, Beukers MW, Schofield PR and IJzerman AP. (1998) Thermodynamics of full agonist, partial agonist, and antagonist binding to wild-type and mutant adenosine A1 receptors. Biochem Pharmacol 56: 1437-45 [PMID:9827575]

70. Daly JW, Hide I, Müller CE and Shamim M. (1991) Caffeine analogs: structure-activity relationships at adenosine receptors. Pharmacology 42: 309-21 [PMID:1658821]

71. Daly JW and Jacobson KA. (1995) Adenosine receptors: selective agonists and antagonists. In Adenosine and adenine nucleotides: from molecular biology to integrative physiology. Edited by Belardinelli L, Pelleg A: Kluwer Academic Publishers: 157-166 [ISBN: 0792331907]

72. Daly JW, Padgett WL, Secunda SI, Thompson RD and Olsson RA. (1993) Structure-activity relationships for 2-substituted adenosines at A1 and A2 adenosine receptors. Pharmacology 46 : 91-100 [PMID:8441759]

73. Das S, Cordis GA, Maulik N and Das DK. (2005) Pharmacological preconditioning with resveratrol: role of CREB-dependent Bcl-2 signaling via adenosine A3 receptor activation. Am J Physiol Heart Circ Physiol 288: H328-35 [PMID:15345477]

74. de Lera Ruiz M, Lim YH and Zheng J. (2014) Adenosine A2A receptor as a drug discovery target. J Med Chem 57: 3623-50 [PMID:24164628]

75. de Ligt RA, Rivkees SA, Lorenzen A, Leurs R and IJzerman AP. (2005) A "locked-on," constitutively active mutant of the adenosine A1 receptor. Eur J Pharmacol 510: 1-8 [PMID:15740718]

76. De Lorenzo S, Veggetti M, Muchnik S and Losavio A. (2004) Presynaptic inhibition of spontaneous acetylcholine release induced by adenosine at the mouse neuromuscular junction. Br J Pharmacol 142: 113-24 [PMID:15066904]

77. Deckert J, Berger W, Kleopa K, Heckers S, Ransmayr G, Heinsen H, Beckmann H and Riederer P. (1993) Adenosine A1 receptors in human hippocampus: inhibition of [3H]8-cyclopentyl-1,3dipropylxanthine binding by antagonist drugs. Neurosci Lett 150: 191-4 [PMID:8469419]

78. Dickenson JM, Reeder S, Rees B, Alexander S and Kendall D. (2003) Functional expression of adenosine A2A and A3 receptors in the mouse dendritic cell line XS-106. EurJ Pharmacol 474: 43-51 [PMID:12909194]

79. Dionisotti S, Ferrara S, Molta C, Zocchi C and Ongini E. (1996) Labeling of A2A adenosine receptors in human platelets by use of the new nonxanthine antagonist radioligand [3H]SCH 58261. J Pharmacol Exp Ther 278: 1209-14 [PMID:8819504]

80. Dionisotti S, Ongini E, Zocchi C, Kull B, Arslan G and Fredholm BB. (1997) Characterization of human A2A adenosine receptors with the antagonist radioligand [3H]-SCH 58261. Br J Pharmacol 121: 353-60 [PMID:9179373]

81. Dolphin AC and Prestwich SA. (1985) Pertussis toxin reverses adenosine inhibition of neuronal glutamate release. Nature 316: 148-50 [PMID:2861569]

82. Dong Q, Ginsberg HN and Erlanger BF. (2001) Overexpression of the A1 adenosine receptor in adipose tissue protects mice from obesity-related insulin resistance. Diabetes Obes Metab 3: 360-6 [PMID:11703426]

83. Donoso MV, Aedo F and Huidobro-Toro JP. (2006) The role of adenosine A2A and A3 receptors on the differential modulation of norepinephrine and neuropeptide $Y$ release from peripheral sympathetic nerve terminals. J Neurochem 96: 1680-95 [PMID:16539684]

84. Donoso MV, López R, Miranda R, Briones R and Huidobro-Toro JP. (2005) A2B adenosine receptor mediates human chorionic vasoconstriction and signals through arachidonic acid cascade. Am J Physiol Heart Circ Physiol 288: H2439-49 [PMID:15637124]

85. Doré AS, Robertson N, Errey JC, Ng I, Hollenstein K, Tehan B, Hurrell E, Bennett K, Congreve $\mathrm{M}$ and Magnani $\mathrm{F}$ et al.. (2011) Structure of the adenosine A(2A) receptor in complex with ZM241385 and the xanthines XAC and caffeine. Structure 19: 1283-93 [PMID:21885291] 
86. Draper-Joyce CJ, Khoshouei M, Thal DM, Liang YL, Nguyen ATN, Furness SGB, Venugopal H, Baltos JA, Plitzko JM and Danev R et al.. (2018) Structure of the adenosine-bound human adenosine $A_{1}$ receptor- $G_{i}$ complex. Nature 558: 559-563 [PMID:29925945]

87. Du X, Ou X, Song T, Zhang W, Cong F, Zhang S and Xiong Y. (2015) Adenosine A2B receptor stimulates angiogenesis by inducing VEGF and eNOS in human microvascular endothelial cells. Exp Biol Med (Maywood) 240: 1472-9 [PMID:25966978]

88. Dubey RK, Gillespie DG, Mi Z and Jackson EK. (2005) Adenosine inhibits PDGF-induced growth of human glomerular mesangial cells via $\mathrm{A}(2 \mathrm{~B})$ receptors. Hypertension 46: 628-34 [PMID:16103269]

89. Dulla CG, Dobelis P, Pearson T, Frenguelli BG, Staley KJ and Masino SA. (2005) Adenosine and ATP link PCO2 to cortical excitability via pH. Neuron 48: 1011-23 [PMID:16364904]

90. Eastwood P, Gonzalez J, Paredes S, Nueda A, Domenech T, Alberti J and Vidal B. (2010) Discovery of N-(5,6-diarylpyridin-2-yl)amide derivatives as potent and selective A(2B) adenosine receptor antagonists. Bioorg Med Chem Lett 20: 1697-700 [PMID:20137946]

91. Eckle T, Faigle M, Grenz A, Laucher S, Thompson LF and Eltzschig HK. (2008) A2B adenosine receptor dampens hypoxia-induced vascular leak. Blood 111: 2024-35 [PMID:18056839]

92. Eckle T, Krahn T, Grenz A, Köhler D, Mittelbronn M, Ledent C, Jacobson MA, Osswald H, Thompson LF and Unertl K et al.. (2007) Cardioprotection by ecto-5'-nucleotidase (CD73) and A2B adenosine receptors. Circulation 115: 1581-90 [PMID:17353435]

93. El Maatougui A, Azuaje J, González-Gómez M, Miguez G, Crespo A, Carbajales C, Escalante L, García-Mera X, Gutiérrez-de-Terán H and Sotelo E. (2016) Discovery of Potent and Highly Selective A2B Adenosine Receptor Antagonist Chemotypes. J Med Chem 59: 1967-83 [PMID:26824742]

94. El Yacoubi M, Ledent C, Parmentier M, Daoust M, Costentin J and Vaugeois J. (2001) Absence of the adenosine $\mathrm{A}(2 \mathrm{~A})$ receptor or its chronic blockade decrease ethanol withdrawal-induced seizures in mice. Neuropharmacology 40: 424-32 [PMID:11166335]

95. Elzein E, Kalla RV, Li X, Perry T, Gimbel A, Zeng D, Lustig D, Leung K and Zablocki J. (2008) Discovery of a novel A2B adenosine receptor antagonist as a clinical candidate for chronic inflammatory airway diseases. J Med Chem 51: 2267-78 [PMID:18321039]

96. Elzein E and Zablocki J. (2008) A1 adenosine receptor agonists and their potential therapeutic applications. Expert Opin Investig Drugs 17: 1901-10 [PMID:19012505]

97. Engelen DP, Koopman JP, van der Brink ME, Bakker MH, Stadhouders AM and de Boer $\mathrm{H}$. (1990) Differences in the intestinal microflora of normal and dystrophic BIO 8262 Nij Syrian hamsters. Z Versuchstierkd 33: 91-6 [PMID:2353549]

98. Ezeamuzie CI and Philips E. (1999) Adenosine A3 receptors on human eosinophils mediate inhibition of degranulation and superoxide anion release. Br J Pharmacol 127: 188-94 [PMID:10369472]

99. Fedorova IM, Jacobson MA, Basile A and Jacobson KA. (2003) Behavioral characterization of mice lacking the A3 adenosine receptor: sensitivity to hypoxic neurodegeneration. Cell $\mathrm{Mol}$ Neurobiol 23: 431-47 [PMID:12825837]

100. Feoktistov I and Biaggioni I. (1995) Adenosine A2b receptors evoke interleukin-8 secretion in human mast cells. An enprofylline-sensitive mechanism with implications for asthma. J Clin Invest 96: 1979-86 [PMID:7560091]

101. Feoktistov I, Garland EM, Goldstein AE, Zeng D, Belardinelli L, Wells JN and Biaggioni I. (2001) Inhibition of human mast cell activation with the novel selective adenosine $\mathrm{A}(2 \mathrm{~B})$ receptor antagonist 3-isobutyl-8-pyrrolidinoxanthine (IPDX)(2). Biochem Pharmacol 62: 1163-73 [PMID:11705449]

102. Fozard JR, Baur F and Wolber C. (2003) Antagonist pharmacology of adenosine A2B receptors from rat, guinea pig and dog. Eur J Pharmacol 475: 79-84 [PMID:12954362]

103. Fozard JR, Pfannkuche HJ and Schuurman HJ. (1996) Mast cell degranulation following adenosine A3 receptor activation in rats. Eur J Pharmacol 298: 293-7 [PMID:8846829]

104. Franchetti P, Cappellacci L, Marchetti S, Trincavelli L, Martini C, Mazzoni MR, Lucacchini A and Grifantini M. (1998) 2'-C-Methyl analogues of selective adenosine receptor agonists: synthesis and binding studies. J Med Chem 41: 1708-15 [PMID:9572897]

105. Franchetti P, Cappellacci L, Vita P, Petrelli R, Lavecchia A, Kachler S, Klotz KN, Marabese I, Luongo L and Maione S et al.. (2009) N6-Cycloalkyl- and N6-bicycloalkyl-C5'(C2')-modified adenosine derivatives as high-affinity and selective agonists at the human A1 adenosine receptor with antinociceptive effects in mice. J Med Chem 52: 2393-406 [PMID:19317449]

106. Fredholm BB. (1995) Astra Award Lecture. Adenosine, adenosine receptors and the actions of caffeine. Pharmacol Toxicol 76: 93-101 [PMID:7746802]

107. Fredholm BB, Abbracchio MP, Burnstock G, Daly JW, Harden TK, Jacobson KA, Leff P and Williams M. (1994) Nomenclature and classification of purinoceptors. Pharmacol Rev 46: 143-56 [PMID:7938164]

108. Fredholm BB, Abbracchio MP, Burnstock G, Dubyak GR, Harden TK, Jacobson KA, Schwabe U and Williams M. (1997) Towards a revised nomenclature for P1 and P2 receptors. Trends 
Pharmacol Sci 18: 79-82 [PMID:9133776]

109. Fredholm BB, Chen JF, Masino SA and Vaugeois JM. (2005) Actions of adenosine at its receptors in the CNS: insights from knockouts and drugs. Annu Rev Pharmacol Toxicol 45: 385-412 [PMID:15822182]

110. Fredholm BB, IJzerman AP, Jacobson KA, Klotz KN and Linden J. (2001) International Union of Pharmacology. XXV. Nomenclature and classification of adenosine receptors. Pharmacol Rev 53 527-52 [PMID:11734617]

111. Fredholm BB, IJzerman AP, Jacobson KA, Linden J and Müller CE. (2011) International Union of Basic and Clinical Pharmacology. LXXXI. Nomenclature and classification of adenosine receptors--an update. Pharmacol Rev 63: 1-34 [PMID:21303899]

112. Fresco P, Diniz C and Gonçalves J. (2004) Facilitation of noradrenaline release by activation of adenosine $\mathrm{A}(2 \mathrm{~A})$ receptors triggers both phospholipase $\mathrm{C}$ and adenylate cyclase pathways in rat tail artery. Cardiovasc Res 63: 739-46 [PMID:15306230]

113. Furlong TJ, Pierce KD, Selbie LA and Shine J. (1992) Molecular characterization of a human brain adenosine A2 receptor. Brain Res Mol Brain Res 15: 62-6 [PMID:1331670]

114. Furuta S, Onodera K, Kumagai M, Honma I, Miyazaki S, Sato T and Sakurada S. (2003) Involvement of adenosine A1 receptors in forced walking stress-induced analgesia in mice. Methods Find Exp Clin Pharmacol 25: 793-6 [PMID:14735226]

115. Gallo-Rodriguez C, Ji XD, Melman N, Siegman BD, Sanders LH, Orlina J, Fischer B, Pu Q, Olah ME and van Galen PJ et al.. (1994) Structure-activity relationships of N6-benzyladenosine-5'uronamides as A3-selective adenosine agonists. J Med Chem 37: 636-46 [PMID:8126704]

116. Gao ZG, Jiang Q, Jacobson KA and Ijzerman AP. (2000) Site-directed mutagenesis studies of human $\mathrm{A}(2 \mathrm{~A})$ adenosine receptors: involvement of glu(13) and his(278) in ligand binding and sodium modulation. Biochem Pharmacol 60: 661-8 [PMID:10927024]

117. Gao ZG, Mamedova LK, Chen P and Jacobson KA. (2004) 2-Substituted adenosine derivatives: affinity and efficacy at four subtypes of human adenosine receptors. Biochem Pharmacol 68: 1985-93 [PMID:15476669]

118. Garber K. (2017) Adenosine checkpoint agent blazes a trail, joins immunotherapy roster. Nat Biotechnol 35: 805-807 [PMID:28898225]

119. García-Nafría J, Lee Y, Bai X, Carpenter B and Tate CG. (2018) Cryo-EM structure of the adenosine $\mathrm{A}_{2 \mathrm{~A}}$ receptor coupled to an engineered heterotrimeric $\mathrm{G}$ protein. Elife 7 [PMID:29726815]

120. Germack R and Dickenson JM. (2005) Adenosine triggers preconditioning through MEK/ERK1/2 signalling pathway during hypoxia/reoxygenation in neonatal rat cardiomyocytes. J Mol Cell Cardiol 39: 429-42 [PMID:16005018]

121. Germack R, Griffin M and Dickenson JM. (2004) Activation of protein kinase B by adenosine A1 and A3 receptors in newborn rat cardiomyocytes. J Mol Cell Cardiol 37: 989-99 [PMID:15522276]

122. Gerwins P and Fredholm BB. (1991) Glucocorticoid receptor activation leads to up-regulation of adenosine A1 receptors and down-regulation of adenosine A2 responses in DDT1 MF-2 smooth muscle cells. Mol Pharmacol 40: 149-55 [PMID:1652051]

123. Ghanem E, Lövdahl C, Daré E, Ledent C, Fredholm BB, Boeynaems JM, Van Driessche W and Beauwens R. (2005) Luminal adenosine stimulates chloride secretion through A1 receptor in mouse jejunum. Am J Physiol Gastrointest Liver Physiol 288: G972-7 [PMID:15637180]

124. Giffin NJ, Kowacs F, Libri V, Williams P, Goadsby PJ and Kaube H. (2003) Effect of the adenosine A1 receptor agonist GR79236 on trigeminal nociception with blink reflex recordings in healthy human subjects. Cephalalgia 23: 287-92 [PMID:12716347]

125. Gillespie RJ, Bamford SJ, Botting R, Comer M, Denny S, Gaur S, Griffin M, Jordan AM, Knight AR and Lerpiniere J et al.. (2009) Antagonists of the human A(2A) adenosine receptor. 4. Design, synthesis, and preclinical evaluation of 7-aryltriazolo[4,5-d]pyrimidines. J Med Chem 52: 33-47 [PMID:19072055]

126. Giménez-Llort L, Fernández-Teruel A, Escorihuela RM, Fredholm BB, Tobeña A, Pekny M and Johansson B. (2002) Mice lacking the adenosine A1 receptor are anxious and aggressive, but are normal learners with reduced muscle strength and survival rate. Eur J Neurosci 16: 547-550 [PMID:12193199]

127. Giménez-Llort L, Masino SA, Diao L, Fernández-Teruel A, Tobeña A, Halldner L and Fredholm BB. (2005) Mice lacking the adenosine A1 receptor have normal spatial learning and plasticity in the CA1 region of the hippocampus, but they habituate more slowly. Synapse 57: 8-16 [PMID:15858837]

128. Glukhova A, Thal DM, Nguyen AT, Vecchio EA, Jörg M, Scammells PJ, May LT, Sexton PM and Christopoulos A. (2017) Structure of the Adenosine A1 Receptor Reveals the Basis for Subtype Selectivity. Cell 168: 867-877.e13 [PMID:28235198]

129. Gomez JAC and Laria JCC-P. (2011) 4-aminopyrimidine derivatives and their as as adenosine $A_{2 A}$ receptor antagonists Patent number: WO2011121418A1.

130. González-Benítez E, Guinzberg R, Díaz-Cruz A and Piña E. (2002) Regulation of glycogen 
metabolism in hepatocytes through adenosine receptors. Role of Ca2+ and cAMP. Eur J Pharmacol 437: 105-11 [PMID:11890897]

131. Grahner B, Winiwarter S, Lanzner W and Müller CE. (1994) Synthesis and structure-activity relationships of deazaxanthines: analogs of potent A1- and A2-adenosine receptor antagonists. $J$ Med Chem 37: 1526-34 [PMID:8182711]

132. Guo D, Mulder-Krieger T, IJzerman AP and Heitman LH. (2012) Functional efficacy of adenosine $\mathrm{A}_{2} \mathrm{~A}$ receptor agonists is positively correlated to their receptor residence time. Br J Pharmacol 166: 1846-59 [PMID:22324512]

133. Guo D, Peletier LA, Bridge L, Keur W, de Vries H, Zweemer A, Heitman LH and IJzerman AP. (2018) A two-state model for the kinetics of competitive radioligand binding. Br J Pharmacol 175: 1719-1730 [PMID:29486053]

134. Guo Y, Bolli R, Bao W, Wu WJ, Black Jr RG, Murphree SS, Salvatore CA, Jacobson MA and Auchampach JA. (2001) Targeted deletion of the A3 adenosine receptor confers resistance to myocardial ischemic injury and does not prevent early preconditioning. J Mol Cell Cardiol 33: 825-30 [PMID:11273734]

135. Göblyös A, Gao ZG, Brussee J, Connestari R, Santiago SN, Ye K, Ijzerman AP and Jacobson KA. (2006) Structure-activity relationships of new $1 \mathrm{H}$-imidazo[4,5-c]quinolin-4-amine derivatives as allosteric enhancers of the A3 adenosine receptor. J Med Chem 49: 3354-61 [PMID:16722654]

136. Hammarberg C, Fredholm BB and Schulte G. (2004) Adenosine A3 receptor-mediated regulation of p38 and extracellular-regulated kinase ERK1/2 via phosphatidylinositol-3'-kinase. Biochem Pharmacol 67: 129-134 [PMID:14667935]

137. Haskó G, Linden J, Cronstein B and Pacher P. (2008) Adenosine receptors: therapeutic aspects for inflammatory and immune diseases. Nat Rev Drug Discov 7: 759-70 [PMID:18758473]

138. Hayallah AM, Sandoval-Ramírez J, Reith U, Schobert U, Preiss B, Schumacher B, Daly JW and Müller CE. (2002) 1,8-disubstituted xanthine derivatives: synthesis of potent A2B-selective adenosine receptor antagonists. J Med Chem 45: 1500-10 [PMID:11906291]

139. He W, Wilder T and Cronstein BN. (2013) Rolofylline, an adenosine A1 receptor antagonist, inhibits osteoclast differentiation as an inverse agonist. BrJ Pharmacol 170: 1167-76 [PMID:23962057]

140. Heitman LH, Göblyös A, Zweemer AM, Bakker R, Mulder-Krieger T, van Veldhoven JP, de Vries $\mathrm{H}$, Brussee J and Ijzerman AP. (2009) A series of 2,4-disubstituted quinolines as a new class of allosteric enhancers of the adenosine A3 receptor. J Med Chem 52: 926-31 [PMID:19161279]

141. Heitman LH, Mulder-Krieger T, Spanjersberg RF, von Frijtag Drabbe Künzel JK, Dalpiaz A and IJzerman AP. (2006) Allosteric modulation, thermodynamics and binding to wild-type and mutant (T277A) adenosine A1 receptors of LUF5831, a novel nonadenosine-like agonist. $\mathrm{Br} \mathrm{J}$ Pharmacol 147: 533-41 [PMID:16444290]

142. Hino T, Arakawa T, Iwanari H, Yurugi-Kobayashi T, Ikeda-Suno C, Nakada-Nakura Y, KusanoArai O, Weyand S, Shimamura T and Nomura N et al.. (2012) G-protein-coupled receptor inactivation by an allosteric inverse-agonist antibody. Nature 482: 237-40 [PMID:22286059]

143. Hinschen AK, Rose'Meyer RB and Headrick JP. (2003) Adenosine receptor subtypes mediating coronary vasodilation in rat hearts. J Cardiovasc Pharmacol 41: 73-80 [PMID:12500024]

144. Hirai $\mathrm{H}$ and Okada Y. (1995) Adenosine facilitates in vivo neurotransmission in the superior colliculus of the rat. $J$ Neurophysiol 74: 950-60 [PMID:7500164]

145. Hofer M, Pospíšil M, Dušek L, Hoferová Z, Weiterová L and Komůrková D. (2013) Erythropoiesis- and thrombopoiesis-characterizing parameters in adenosine A3 receptor knockout mice. Physiol Res 62: 305-11 [PMID:23489188]

146. Hoffman AF, Laaris N, Kawamura M, Masino SA and Lupica CR. (2010) Control of cannabinoid CB1 receptor function on glutamate axon terminals by endogenous adenosine acting at A1 receptors. J Neurosci 30: 545-55 [PMID:20071517]

147. Holschbach MH, Olsson RA, Bier D, Wutz W, Sihver W, Schüller M, Palm B and Coenen HH. (2002) Synthesis and evaluation of no-carrier-added 8-cyclopentyl-3-(3-[(18)F]fluoropropyl)-1propylxanthine ([(18)F]CPFPX): a potent and selective A(1)-adenosine receptor antagonist for in vivo imaging. $J$ Med Chem 45: 5150-6 [PMID:12408725]

148. Hua X, Chason KD, Fredholm BB, Deshpande DA, Penn RB and Tilley SL. (2008) Adenosine induces airway hyperresponsiveness through activation of A3 receptors on mast cells. J Allergy Clin Immunol 122: 107-13, 113.e1-7 [PMID:18472152]

149. Huang ZL, Qu WM, Eguchi N, Chen JF, Schwarzschild MA, Fredholm BB, Urade Y and Hayaishi O. (2005) Adenosine A2A, but not A1, receptors mediate the arousal effect of caffeine. Nat Neurosci 8: 858-9 [PMID:15965471]

150. Härter M, Kalthof B, Delbeck M, Lustig K, Gerisch M, Schulz S, Kast R, Meibom D and Lindner N. (2019) Novel non-xanthine antagonist of the $A_{2 B}$ adenosine receptor: From HTS hit to lead structure. Eur J Med Chem 163: 763-778 [PMID:30576906]

151. Imlach WL, Bhola RF, May LT, Christopoulos A and Christie MJ. (2015) A Positive Allosteric Modulator of the Adenosine A1 Receptor Selectively Inhibits Primary Afferent Synaptic Transmission in a Neuropathic Pain Model. Mol Pharmacol 88: 460-8 [PMID:26104547] 
152. Iredale PA, Alexander SP and Hill SJ. (1994) Coupling of a transfected human brain A1 adenosine receptor in CHO-K1 cells to calcium mobilisation via a pertussis toxin-sensitive mechanism. Br J Pharmacol 111: 1252-6 [PMID:8032613]

153. Jaakola VP, Griffith MT, Hanson MA, Cherezov V, Chien EY, Lane JR, Ijzerman AP and Stevens RC. (2008) The 2.6 angstrom crystal structure of a human A2A adenosine receptor bound to an antagonist. Science 322: 1211-7 [PMID:18832607]

154. Jacobson KA IJzerman AP and Linden J. (1999) 1,3-Dialkylxanthine derivatives having high potency as antagonists at human A2B adenosine receptors. Drug Dev Res: 45-53

155. Jacobson KA, Fischer B and Ji XD. (1995) "Cleavable trifunctional" approach to receptor affinity labeling: chemical regeneration of binding to A1-adenosine receptors. Bioconjug Chem 6: 25563 [PMID:7632796]

156. Jacobson KA, Gallo-Rodriguez C, Melman N, Fischer B, Maillard M, van Bergen A, van Galen PJ and Karton Y. (1993) Structure-activity relationships of 8-styrylxanthines as A2-selective adenosine antagonists. J Med Chem 36: 1333-42 [PMID:8496902]

157. Jacobson KA and Gao ZG. (2006) Adenosine receptors as therapeutic targets. Nat Rev Drug Discov 5: 247-64 [PMID:16518376]

158. Jacobson KA, Kim HO, Siddiqi SM, Olah ME, Stiles GL and von Lubitz DKJE. (1995) $\mathrm{A}_{3}$ adenosine receptors: design of selective ligands and therapeutic prospects. Drugs Future 20: 689-699

159. Jacobson KA, Park KS, Jiang JL, Kim YC, Olah ME, Stiles GL and Ji XD. (1997) Pharmacological characterization of novel A3 adenosine receptor-selective antagonists. Neuropharmacology 36: 1157-65 [PMID:9364471]

160. Jacobson MA, Johnson RG, Luneau CJ and Salvatore CA. (1995) Cloning and chromosomal localization of the human A2b adenosine receptor gene (ADORA2B) and its pseudogene. Genomics 27: 374-6 [PMID:7558011]

161. Jarvis MF, Schulz R, Hutchison AJ, Do UH, Sills MA and Williams M. (1989) [3H]CGS 21680, a selective A2 adenosine receptor agonist directly labels A2 receptors in rat brain. J Pharmacol Exp Ther 251: 888-93 [PMID:2600819]

162. Jenner P. (2003) A2A antagonists as novel non-dopaminergic therapy for motor dysfunction in PD. Neurology 61: S32-8 [PMID:14663007]

163. Jenner P. (2005) Istradefylline, a novel adenosine A2A receptor antagonist, for the treatment of Parkinson's disease. Expert Opin Investig Drugs 14: 729-38 [PMID:16004599]

164. Ji X, Kim YC, Ahern DG, Linden J and Jacobson KA. (2001) [3H]MRS 1754, a selective antagonist radioligand for A(2B) adenosine receptors. Biochem Pharmacol 61: 657-63 [PMID:11266650]

165. Ji XD and Jacobson KA. (1999) Use of the triazolotriazine [3H]ZM 241385 as a radioligand at recombinant human A2B adenosine receptors. Drug Des Discov 16: 217-26 [PMID:10624567]

166. Jiang JL, van Rhee AM, Melman N, Ji XD and Jacobson KA. (1996) 6-phenyl-1,4-dihydropyridine derivatives as potent and selective A3 adenosine receptor antagonists. J Med Chem 39: 4667-75 [PMID:8917655]

167. Jockers R, Linder ME, Hohenegger M, Nanoff C, Bertin B, Strosberg AD, Marullo S and Freissmuth M. (1994) Species difference in the G protein selectivity of the human and bovine A1-adenosine receptor. J Biol Chem 269: 32077-84 [PMID:7798201]

168. Johansson B and Fredholm BB. (1995) Further characterization of the binding of the adenosine receptor agonist [3H]CGS 21680 to rat brain using autoradiography. Neuropharmacology 34: 393-403 [PMID:7566470]

169. Johansson B, Georgiev V, Parkinson FE and Fredholm BB. (1993) The binding of the adenosine A2 receptor selective agonist [3H]CGS 21680 to rat cortex differs from its binding to rat striatum. Eur J Pharmacol 247: 103-10 [PMID:8281998]

170. Johansson B, Halldner L, Dunwiddie TV, Masino SA, Poelchen W, Giménez-Llort L, Escorihuela RM, Fernández-Teruel A, Wiesenfeld-Hallin Z and Xu XJ et al.. (2001) Hyperalgesia, anxiety, and decreased hypoxic neuroprotection in mice lacking the adenosine A1 receptor. Proc Natl Acad Sci USA 98: 9407-12 [PMID:11470917]

171. Johansson SM, Lindgren E, Yang JN, Herling AW and Fredholm BB. (2008) Adenosine A1 receptors regulate lipolysis and lipogenesis in mouse adipose tissue-interactions with insulin. Eur J Pharmacol 597: 92-101 [PMID:18789919]

172. Johansson SM, Yang JN, Lindgren E and Fredholm BB. (2007) Eliminating the antilipolytic adenosine A1 receptor does not lead to compensatory changes in the antilipolytic actions of PGE2 and nicotinic acid. Acta Physiol (Oxf) 190: 87-96 [PMID:17428236]

173. Kalk P, Eggert B, Relle K, Godes M, Heiden S, Sharkovska Y, Fischer Y, Ziegler D, Bielenberg GW and Hocher B. (2007) The adenosine A1 receptor antagonist SLV320 reduces myocardial fibrosis in rats with 5/6 nephrectomy without affecting blood pressure. Br J Pharmacol 151: 1025-32 [PMID:17558436]

174. Kara FM, Chitu V, Sloane J, Axelrod M, Fredholm BB, Stanley ER and Cronstein BN. (2010) Adenosine A1 receptors (A1Rs) play a critical role in osteoclast formation and function. FASEB J 24: 2325-33 [PMID:20181934] 
175. Kara FM, Doty SB, Boskey A, Goldring S, Zaidi M, Fredholm BB and Cronstein BN. (2010) Adenosine $\mathrm{A}(1)$ receptors regulate bone resorption in mice: adenosine $\mathrm{A}(1)$ receptor blockade or deletion increases bone density and prevents ovariectomy-induced bone loss in adenosine $\mathrm{A}(1)$ receptor-knockout mice. Arthritis Rheum 62: 534-41 [PMID:20112380]

176. Karlsten R, Gordh Jr T, Hartvig P and Post C. (1990) Effects of intrathecal injection of the adenosine receptor agonists R-phenylisopropyl-adenosine and $\mathrm{N}$-ethylcarboxamide-adenosine on nociception and motor function in the rat. Anesth Analg 71: 60-4 [PMID:2363530]

177. Karton Y, Jiang JL, Ji XD, Melman N, Olah ME, Stiles GL and Jacobson KA. (1996) Synthesis and biological activities of flavonoid derivatives as A3 adenosine receptor antagonists. J Med Chem 39: 2293-301 [PMID:8691424]

178. Kase H, Aoyama S, Ichimura M, Ikeda K, Ishii A, Kanda T, Koga K, Koike N, Kurokawa M and Kuwana Y et al.. (2003) Progress in pursuit of therapeutic A2A antagonists: the adenosine A2A receptor selective antagonist KW6002: research and development toward a novel nondopaminergic therapy for Parkinson's disease. Neurology 61: S97-100 [PMID:14663020]

179. Katritch V, Jaakola VP, Lane JR, Lin J, Ijzerman AP, Yeager M, Kufareva I, Stevens RC and Abagyan R. (2010) Structure-based discovery of novel chemotypes for adenosine A(2A) receptor antagonists. J Med Chem 53: 1799-809 [PMID:20095623]

180. Kemp BK and Cocks TM. (1999) Adenosine mediates relaxation of human small resistance-like coronary arteries via A2B receptors. Br J Pharmacol 126: 1796-800 [PMID:10372822]

181. Kiesman WF, Zhao J, Conlon PR, Dowling JE, Petter RC, Lutterodt F, Jin X, Smits G, Fure M and Jayaraj A et al.. (2006) Potent and orally bioavailable 8-bicyclo[2.2.2] octylxanthines as adenosine A1 receptor antagonists. J Med Chem 49: 7119-31 [PMID:17125264]

182. Kiesman WF, Zhao J, Conlon PR, Petter RC, Jin X, Smits G, Lutterodt F, Sullivan GW and Linden J. (2006) Norbornyllactone-substituted xanthines as adenosine A(1) receptor antagonists. Bioorg Med Chem 14: 3654-61 [PMID:16458010]

183. Kim HO, Ji XD, Siddiqi SM, Olah ME, Stiles GL and Jacobson KA. (1994) 2-Substitution of N6benzyladenosine-5'-uronamides enhances selectivity for A3 adenosine receptors. J Med Chem 37: 3614-21 [PMID:7932588]

184. Kim J, Wess J, van Rhee AM, Schöneberg T and Jacobson KA. (1995) Site-directed mutagenesis identifies residues involved in ligand recognition in the human A2a adenosine receptor. J Biol Chem 270: 13987-97 [PMID:7775460]

185. Kim SA, Marshall MA, Melman N, Kim HS, Müller CE, Linden J and Jacobson KA. (2002) Structure-activity relationships at human and rat A2B adenosine receptors of xanthine derivatives substituted at the 1-, 3-, 7-, and 8-positions. J Med Chem 45: 2131-8 [PMID:12014951]

186. Kim Y, de Castro S, Gao ZG, Ijzerman AP and Jacobson KA. (2009) Novel 2- and 4-substituted $1 \mathrm{H}$-imidazo[4,5-c]quinolin-4-amine derivatives as allosteric modulators of the A3 adenosine receptor. J Med Chem 52: 2098-108 [PMID:19284749]

187. Kim YC, Ji X, Melman N, Linden J and Jacobson KA. (2000) Anilide derivatives of an 8phenylxanthine carboxylic congener are highly potent and selective antagonists at human $\mathrm{A}(2 \mathrm{~B})$ adenosine receptors. J Med Chem 43: 1165-72 [PMID:10737749]

188. Kim YC, Ji XD and Jacobson KA. (1996) Derivatives of the triazoloquinazoline adenosine antagonist (CGS15943) are selective for the human A3 receptor subtype. J Med Chem 39: 41428 [PMID:8863790]

189. Kirchhof P, Fabritz L, Fortmuller L, Matherne GP, Lankford A, Baba HA, Schmitz W, Breithardt G, Neumann J and Boknik P. (2003) Altered sinus nodal and atrioventricular nodal function in freely moving mice overexpressing the A1 adenosine receptor. Am J Physiol Heart Circ Physiol 285: H145-53 [PMID:12637351]

190. Klotz KN, Falgner N, Kachler S, Lambertucci C, Vittori S, Volpini R and Cristalli G. (2007) [3H]HEMADO--a novel tritiated agonist selective for the human adenosine A3 receptor. Eur J Pharmacol 556: 14-8 [PMID:17126322]

191. Klotz KN, Hessling J, Hegler J, Owman C, Kull B, Fredholm BB and Lohse MJ. (1998) Comparative pharmacology of human adenosine receptor subtypes - characterization of stably transfected receptors in CHO cells. Naunyn Schmiedebergs Arch Pharmacol 357: 1-9 [PMID:9459566]

192. Klotz KN, Vogt H and Tawfik-Schlieper H. (1991) Comparison of A1 adenosine receptors in brain from different species by radioligand binding and photoaffinity labelling. Naunyn Schmiedebergs Arch Pharmacol 343: 196-201 [PMID:2067592]

193. Kochanek PM, Vagni VA, Janesko KL, Washington CB, Crumrine PK, Garman RH, Jenkins LW, Clark RS, Homanics GE and Dixon CE et al.. (2006) Adenosine A1 receptor knockout mice develop lethal status epilepticus after experimental traumatic brain injury. J Cereb Blood Flow Metab 26: 565-75 [PMID:16121125]

194. Kolb P, Phan K, Gao ZG, Marko AC, Sali A and Jacobson KA. (2012) Limits of ligand selectivity from docking to models: in silico screening for $\mathrm{A}(1)$ adenosine receptor antagonists. PLoS ONE 7: e49910 [PMID:23185482] 
195. Kull B, Arslan G, Nilsson C, Owman C, Lorenzen A, Schwabe U and Fredholm BB. (1999) Differences in the order of potency for agonists but not antagonists at human and rat adenosine A2A receptors. Biochem Pharmacol 57: 65-75 [PMID:9920286]

196. Kull B, Svenningsson P and Fredholm BB. (2000) Adenosine A(2A) receptors are colocalized with and activate g(olf) in rat striatum. Mol Pharmacol 58: 771-7 [PMID:10999947]

197. Kuno A, Critz SD, Cui L, Solodushko V, Yang XM, Krahn T, Albrecht B, Philipp S, Cohen MV and Downey JM. (2007) Protein kinase C protects preconditioned rabbit hearts by increasing sensitivity of adenosine A2b-dependent signaling during early reperfusion. J Mol Cell Cardiol 43: 262-71 [PMID:17632123]

198. Lang UE, Lang F, Richter K, Vallon V, Lipp HP, Schnermann J and Wolfer DP. (2003) Emotional instability but intact spatial cognition in adenosine receptor 1 knock out mice. Behav Brain Res 145: 179-88 [PMID:14529816]

199. Langmead CJ, Andrews SP, Congreve M, Errey JC, Hurrell E, Marshall FH, Mason JS, Richardson CM, Robertson N and Zhukov A et al.. (2012) Identification of novel adenosine A(2A) receptor antagonists by virtual screening. J Med Chem 55: 1904-9 [PMID:22250781]

200. Lankford AR, Yang JN, Rose'Meyer R, French BA, Matherne GP, Fredholm BB and Yang Z. (2006) Effect of modulating cardiac A1 adenosine receptor expression on protection with ischemic preconditioning. Am J Physiol Heart Circ Physiol 290: H1469-73 [PMID:16299262]

201. Lappas CM, Rieger JM and Linden J. (2005) A2A adenosine receptor induction inhibits IFNgamma production in murine CD4+ T cells. J Immunol 174: 1073-80 [PMID:15634932]

202. Le F, Townsend-Nicholson A, Baker E, Sutherland GR and Schofield PR. (1996) Characterization and chromosomal localization of the human A2a adenosine receptor gene: ADORA2A. Biochem Biophys Res Commun 223: 461-7 [PMID:8670304]

203. Lebon G, Edwards PC, Leslie AG and Tate CG. (2015) Molecular Determinants of CGS21680 Binding to the Human Adenosine A2A Receptor. Mol Pharmacol 87: 907-15 [PMID:25762024]

204. Lebon G, Warne T, Edwards PC, Bennett K, Langmead CJ, Leslie AG and Tate CG. (2011) Agonist-bound adenosine A2A receptor structures reveal common features of GPCR activation. Nature 474: 521-5 [PMID:21593763]

205. Lebon G, Warne T, Edwards PC, Bennett K, Langmead CJ, Leslie AG and Tate CG. (2011) Agonist-bound adenosine A2A receptor structures reveal common features of GPCR activation. Nature 474: 521-5 [PMID:21593763]

206. Ledent C, Vaugeois JM, Schiffmann SN, Pedrazzini T, El Yacoubi M, Vanderhaeghen JJ, Costentin J, Heath JK, Vassart G and Parmentier M. (1997) Aggressiveness, hypoalgesia and high blood pressure in mice lacking the adenosine A2a receptor. Nature 388: 674-8 [PMID:9262401]

207. Lee HT, Ota-Setlik A, Xu H, D'Agati VD, Jacobson MA and Emala CW. (2003) A3 adenosine receptor knockout mice are protected against ischemia- and myoglobinuria-induced renal failure. Am J Physiol Renal Physiol 284: F267-73 [PMID:12388399]

208. Lee HT, Xu H, Nasr SH, Schnermann J and Emala CW. (2004) A1 adenosine receptor knockout mice exhibit increased renal injury following ischemia and reperfusion. Am J Physiol Renal Physiol 286: F298-306 [PMID:14600029]

209. Lenselink EB, Beuming T, Sherman W, van Vlijmen HW and IJzerman AP. (2014) Selecting an optimal number of binding site waters to improve virtual screening enrichments against the adenosine A2A receptor. J Chem Inf Model 54: 1737-46 [PMID:24835542]

210. Leone RD, Lo YC and Powell JD. (2015) A2aR antagonists: Next generation checkpoint blockade for cancer immunotherapy. Comput Struct Biotechnol J 13: 265-72 [PMID:25941561]

211. Leung E, Walsh LK, Flippin LA, Kim EJ, Lazar DA, Seran CS, Wong EH and Eglen RM. (1995) Enhancement of adenosine A1 receptor functions by benzoylthiophenes in guinea pig tissues in vitro. Naunyn Schmiedebergs Arch Pharmacol 352: 206-12 [PMID:7477445]

212. Li AH, Moro S, Melman N, Ji XD and Jacobson KA. (1998) Structure-activity relationships and molecular modeling of 3, 5-diacyl-2,4-dialkylpyridine derivatives as selective A3 adenosine receptor antagonists. J Med Chem 41: 3186-201 [PMID:9703464]

213. Li L, Hao JX, Fredholm BB, Schulte G, Wiesenfeld-Hallin Z and Xu XJ. (2010) Peripheral adenosine A2A receptors are involved in carrageenan-induced mechanical hyperalgesia in mice. Neuroscience 170: 923-8 [PMID:20678550]

214. Li Q, Ye K, Blad CC, den Dulk H, Brouwer J, Ijzerman AP and Beukers MW. (2007) ZM241385, DPCPX, MRS1706 are inverse agonists with different relative intrinsic efficacies on constitutively active mutants of the human adenosine A2B receptor. J Pharmacol Exp Ther 320: 637-45 [PMID:17077318]

215. Li W, Dai S, An J, Xiong R, Li P, Chen X, Zhao Y, Liu P, Wang H and Zhu P et al.. (2009) Genetic inactivation of adenosine A2A receptors attenuates acute traumatic brain injury in the mouse cortical impact model. Exp Neurol 215: 69-76 [PMID:18938161]

216. Liang BT, Urso R, Sambraski E and Jacobson KA. (2010) In A3 Adenosine Receptors from Cell Biology to Pharmacology and Therapeutics Edited by Borea PA: Springer: [ISBN: 9789048131440] 
217. Libert F, Van Sande J, Lefort A, Czernilofsky A, Dumont JE, Vassart G, Ensinger HA and Mendla KD. (1992) Cloning and functional characterization of a human A1 adenosine receptor. Biochem Biophys Res Commun 187: 919-26 [PMID:1530647]

218. Linden J, Thai T, Figler H, Jin X and Robeva AS. (1999) Characterization of human A(2B) adenosine receptors: radioligand binding, western blotting, and coupling to $\mathrm{G}(\mathrm{q})$ in human embryonic kidney 293 cells and HMC-1 mast cells. Mol Pharmacol 56: 705-13 [PMID:10496952]

219. Lindström K, Ongini E and Fredholm BB. (1996) The selective adenosine A2A receptor antagonist SCH 58261 discriminates between two different binding sites for [3H]-CGS 21680 in the rat brain. Naunyn Schmiedebergs Arch Pharmacol 354: 539-41 [PMID:8897460]

220. Liu H, Kuang X, Zhang Y, Ye Y, Li J, Liang L, Xie Z, Weng L, Guo J and Li H et al.. (2020) ADORA1 Inhibition Promotes Tumor Immune Evasion by Regulating the ATF3-PD-L1 Axis. Cancer Cell 37: 324-339.e8 [PMID:32183950]

221. Liu W, Chun E, Thompson AA, Chubukov P, Xu F, Katritch V, Han GW, Roth CB, Heitman LH and IJzerman AP et al.. (2012) Structural basis for allosteric regulation of GPCRs by sodium ions. Science 337: 232-6 [PMID:22798613]

222. Lopes LV, Halldner L, Rebola N, Johansson B, Ledent C, Chen JF, Fredholm BB and Cunha RA. (2004) Binding of the prototypical adenosine A(2A) receptor agonist CGS 21680 to the cerebral cortex of adenosine A(1) and A(2A) receptor knockout mice. Br J Pharmacol 141: 1006-1014 [PMID:14993095]

223. Lopes LV, Rebola N, Pinheiro PC, Richardson PJ, Oliveira CR and Cunha RA. (2003) Adenosine A3 receptors are located in neurons of the rat hippocampus. Neuroreport 14: 1645-8 [PMID:14502093]

224. Lorenzen A, Grossekatthöfer B, Kerst B, Vogt H, Fein T and Schwabe U. (1996) Characterization of a novel adenosine binding protein sensitive to cyclic AMP in rat brain cytosolic and particulate fractions. Biochem Pharmacol 52: 1375-85 [PMID:8937447]

225. Müller CE. (2000) $A_{2 A}$ Adenosine receptor antagonists-future drugs for Parkinson's disease? Drugs Future: 1043-1052

226. Müller CE and Stein B. (1996) Adenosine receptor antagonists: structures and potential therapeutic applications. Curr Pharm Des 2: 501-530

227. Ma HC, Wang YF, Feng CS, Zhao H and Dohi S. (2005) Effects of adenosine agonist Rphenylisopropyl-adenosine on halothane anesthesia and antinociception in rats. Acta Pharmacol Sin 26: 181-5 [PMID:15663896]

228. MacGregor DG, Miller WJ and Stone TW. (1993) Mediation of the neuroprotective action of Rphenylisopropyl-adenosine through a centrally located adenosine A1 receptor. Br J Pharmacol 110: 470-6 [PMID:8220909]

229. Maddock HL, Mocanu MM and Yellon DM. (2002) Adenosine A(3) receptor activation protects the myocardium from reperfusion/reoxygenation injury. Am J Physiol Heart Circ Physiol 283: H1307-13 [PMID:12234780]

230. Maemoto T, Tada M, Mihara T, Ueyama N, Matsuoka H, Harada K, Yamaji T, Shirakawa K, Kuroda S and Akahane A et al.. (2004) Pharmacological characterization of FR194921, a new potent, selective, and orally active antagonist for central adenosine A1 receptors. J Pharmacol Sci 96: 42-52 [PMID:15351792]

231. Mahan LC, McVittie LD, Smyk-Randall EM, Nakata H, Monsma Jr FJ, Gerfen CR and Sibley DR. (1991) Cloning and expression of an A1 adenosine receptor from rat brain. Mol Pharmacol 40: 1-7 [PMID:1857334]

232. Marks GA, Shaffery JP, Speciale SG and Birabil CG. (2003) Enhancement of rapid eye movement sleep in the rat by actions at A1 and A2a adenosine receptor subtypes with a differential sensitivity to atropine. Neuroscience 116: 913-20 [PMID:12573729]

233. Marquardt DL, Walker LL and Heinemann S. (1994) Cloning of two adenosine receptor subtypes from mouse bone marrow-derived mast cells. J Immunol 152: 4508-15 [PMID:8157966]

234. Martin PL, Wysocki Jr RJ, Barrett RJ, May JM and Linden J. (1996) Characterization of 8-(Nmethylisopropyl)amino-N6-(5'-endohydroxy- endonorbornyl)-9-methyladenine (WRC-0571), a highly potent and selective, non-xanthine antagonist of A1 adenosine receptors. J Pharmacol Exp Ther 276: 490-9 [PMID:8632314]

235. Matherne GP, Linden J, Byford AM, Gauthier NS and Headrick JP. (1997) Transgenic A1 adenosine receptor overexpression increases myocardial resistance to ischemia. Proc Natl Acad Sci USA 94: 6541-6 [PMID:9177254]

236. Mathôt RA, Van der Wenden EM, Soudijn W, IJzerman AP and Danhof M. (1995) Deoxyribose analogues of N6-cyclopentyladenosine (CPA): partial agonists at the adenosine A1 receptor in vivo. BrJ Pharmacol 116: 1957-64 [PMID:8640332]

237. McPherson JA, Barringhaus KG, Bishop GG, Sanders JM, Rieger JM, Hesselbacher SE, Gimple LW, Powers ER, Macdonald T and Sullivan G et al.. (2001) Adenosine A(2A) receptor stimulation reduces inflammation and neointimal growth in a murine carotid ligation model. Arterioscler Thromb Vasc Biol 21: 791-6 [PMID:11348876]

238. Meade CJ, Worrall L, Hayes D and Protin U. (2002) Induction of interleukin 8 release from the 
HMC-1 mast cell line: synergy between stem cell factor and activators of the adenosine A(2b) receptor. Biochem Pharmacol 64: 317-25 [PMID:12123753]

239. Mediavilla-Varela M, Castro J, Chiappori A, Noyes D, Hernandez DC, Allard B, Stagg J and Antonia SJ. (2017) A Novel Antagonist of the Immune Checkpoint Protein Adenosine A2a Receptor Restores Tumor-Infiltrating Lymphocyte Activity in the Context of the Tumor Microenvironment. Neoplasia 19: 530-536 [PMID:28582704]

240. Meibom D, Albrecht-Küpper B, Diedrichs N, Hübsch W, Kast R, Krämer T, Krenz U, Lerchen HG, Mittendorf J and Nell PG et al.. (2017) Neladenoson Bialanate Hydrochloride: A Prodrug of a Partial Adenosine $A_{1}$ Receptor Agonist for the Chronic Treatment of Heart Diseases.

ChemMedChem 12: 728-737 [PMID:28488817]

241. Melman A, Gao ZG, Kumar D, Wan TC, Gizewski E, Auchampach JA and Jacobson KA. (2008) Design of (N)-methanocarba adenosine 5'-uronamides as species-independent A3 receptorselective agonists. Bioorg Med Chem Lett 18: 2813-9 [PMID:18424135]

242. Minelli A, Allegrucci C, Piomboni P, Mannucci R, Lluis C and Franco R. (2000) Immunolocalization of A1 adenosine receptors in mammalian spermatozoa. $J$ Histochem Cytochem 48: 1163-71 [PMID:10950874]

243. Minelli A, Liguori L, Bellazza I, Mannucci R, Johansson B and Fredholm BB. (2004) Involvement of A1 adenosine receptors in the acquisition of fertilizing capacity. J Androl 25: 286-92 [PMID:14760015]

244. Minetti P, Tinti MO, Carminati P, Castorina M, Di Cesare MA, Di Serio S, Gallo G, Ghirardi O, Giorgi F and Giorgi L et al.. (2005) 2-n-Butyl-9-methyl-8-[1,2,3]triazol-2-yl-9H-purin-6-ylamine and analogues as A2A adenosine receptor antagonists. Design, synthesis, and pharmacological characterization. J Med Chem 48: 6887-96 [PMID:16250647]

245. Mirabet M, Herrera C, Cordero OJ, Mallol J, Lluis C and Franco R. (1999) Expression of A2B adenosine receptors in human lymphocytes: their role in T cell activation. J Cell Sci 112 ( Pt 4): 491-502 [PMID:9914161]

246. Montesinos MC, Desai A, Chen JF, Yee H, Schwarzschild MA, Fink JS and Cronstein BN. (2002) Adenosine promotes wound healing and mediates angiogenesis in response to tissue injury via occupancy of A(2A) receptors. Am J Pathol 160: 2009-18 [PMID:12057906]

247. Mudumbi RV, Montamat SC, Bruns RF and Vestal RE. (1993) Cardiac functional responses to adenosine by PD 81,723, an allosteric enhancer of the adenosine A1 receptor. Am J Physiol 264: H1017-22 [PMID:8456969]

248. Murray RD and Churchill PC. (1984) Effects of adenosine receptor agonists in the isolated, perfused rat kidney. Am J Physiol 247: H343-8 [PMID:6089592]

249. Murrison EM, Goodson SJ, Edbrooke MR and Harris CA. (1996) Cloning and characterisation of the human adenosine A3 receptor gene. FEBS Lett 384: 243-6 [PMID:8617363]

250. Müller CE, Diekmann M, Thorand M and Ozola V. (2002) [(3)H]8-Ethyl-4-methyl-2-phenyl(8R)-4,5, 7,8-tetrahydro-1H-imidazo[2,1-i]-purin-5-one ([(3)H]PSB-11), a novel high-affinity antagonist radioligand for human A(3) adenosine receptors. Bioorg Med Chem Lett 12: 501-3 [PMID:11814828]

251. Müller CE and Ferré S. (2007) Blocking striatal adenosine A2A receptors: a new strategy for basal ganglia disorders. Recent Pat CNS Drug Discov 2: 1-21 [PMID:18221214]

252. Müller CE and Jacobson KA. (2011) Recent developments in adenosine receptor ligands and their potential as novel drugs. Biochim Biophys Acta 1808: 1290-308 [PMID:21185259]

253. Müller CE, Maurinsh J and Sauer R. (2000) Binding of [3H]MSX-2 (3-(3-hydroxypropyl)-7methyl-8-(m-methoxystyryl)-1-propargylxanthine) to rat striatal membranes--a new, selective antagonist radioligand for A(2A) adenosine receptors. Eur J Pharm Sci 10: 259-65 [PMID:10838015]

254. Müller CE, Shi D, Manning M and Daly JW. (1993) Synthesis of paraxanthine analogs (1,7disubstituted xanthines) and other xanthines unsubstituted at the 3-position: structure-activity relationships at adenosine receptors. J Med Chem 36: 3341-9 [PMID:8230124]

255. Müller CE, Thorand M, Qurishi R, Diekmann M, Jacobson KA, Padgett WL and Daly JW. (2002) Imidazo[2,1-i]purin-5-ones and related tricyclic water-soluble purine derivatives: potent $\mathrm{A}(2 \mathrm{~A})$ and A(3)-adenosine receptor antagonists. J Med Chem 45: 3440-50 [PMID:12139454]

256. Naassila M, Ledent C and Daoust M. (2002) Low ethanol sensitivity and increased ethanol consumption in mice lacking adenosine A2A receptors. J Neurosci 22: 10487-93 [PMID:12451148]

257. Nagel J, Schladebach H, Koch M, Schwienbacher I, Müller CE and Hauber W. (2003) Effects of an adenosine A2A receptor blockade in the nucleus accumbens on locomotion, feeding, and prepulse inhibition in rats. Synapse 49: 279-86 [PMID:12827647]

258. Nakav S, Chaimovitz C, Sufaro Y, Lewis EC, Shaked G, Czeiger D, Zlotnik M and Douvdevani A. (2008) Anti-inflammatory preconditioning by agonists of adenosine A1 receptor. PLoS ONE 3: e2107 [PMID:18461129]

259. Nanoff C, Mitterauer T, Roka F, Hohenegger M and Freissmuth M. (1995) Species differences in A1 adenosine receptor/G protein coupling: identification of a membrane protein that stabilizes 
the association of the receptor/G protein complex. Mol Pharmacol 48: 806-17 [PMID:7476910]

260. Narlawar R, Lane JR, Doddareddy M, Lin J, Brussee J and Ijzerman AP. (2010) Hybrid ortho/allosteric ligands for the adenosine A(1) receptor. J Med Chem 53: 3028-37 [PMID:20345101]

261. Ngai AC, Coyne EF, Meno JR, West GA and Winn HR. (2001) Receptor subtypes mediating adenosine-induced dilation of cerebral arterioles. Am J Physiol Heart Circ Physiol 280: H232935 [PMID:11299238]

262. Nowak M, Lynch L, Yue S, Ohta A, Sitkovsky M, Balk SP and Exley MA. (2010) The A2aR adenosine receptor controls cytokine production in iNKT cells. Eur J Immunol 40: 682-7 [PMID:20039304]

263. Németh ZH, Lutz CS, Csóka B, Deitch EA, Leibovich SJ, Gause WC, Tone M, Pacher P, Vizi ES and Haskó G. (2005) Adenosine augments IL-10 production by macrophages through an A2B receptor-mediated posttranscriptional mechanism. J Immunol 175: 8260-70 [PMID:16339566]

264. O'Shaughnessy CT, Aram JA and Lodge D. (1988) A1 adenosine receptor-mediated block of epileptiform activity induced in zero magnesium in rat neocortex in vitro. Epilepsy Res 2: 294301 [PMID:2461856]

265. Obiefuna PC, Batra VK, Nadeem A, Borron P, Wilson CN and Mustafa SJ. (2005) A novel A1 adenosine receptor antagonist, L-97-1 [3-[2-(4-aminophenyl)-ethyl]-8-benzyl-7-\{2-ethyl-(2hydroxy-ethyl)-amino]-ethyl\}-1-propyl-3,7-dihydro-purine-2,6-dione], reduces allergic responses to house dust mite in an allergic rabbit model of asthma. J Pharmacol Exp Ther 315: 329-36 [PMID:16020631]

266. Ohta A and Sitkovsky M. (2001) Role of G-protein-coupled adenosine receptors in downregulation of inflammation and protection from tissue damage. Nature 414: 916-20 [PMID:11780065]

267. Olah ME. (1997) Identification of A2a adenosine receptor domains involved in selective coupling to Gs. Analysis of chimeric A1/A2a adenosine receptors. J Biol Chem 272: 337-44 [PMID:8995267]

268. Olah ME, Jacobson KA and Stiles GL. (1994) Role of the second extracellular loop of adenosine receptors in agonist and antagonist binding. Analysis of chimeric A1/A3 adenosine receptors. $J$ Biol Chem 269: 24692-8 [PMID:7929142]

269. Olah ME and Stiles GL. (1995) Adenosine receptor subtypes: characterization and therapeutic regulation. Annu Rev Pharmacol Toxicol 35: 581-606 [PMID:7598508]

270. Olsson T, Cronberg T, Rytter A, Asztély F, Fredholm BB, Smith ML and Wieloch T. (2004) Deletion of the adenosine A1 receptor gene does not alter neuronal damage following ischaemia in vivo or in vitro. Eur J Neurosci 20: 1197-204 [PMID:15341591]

271. Ongini E, Dionisotti S, Gessi S, Irenius E and Fredholm BB. (1999) Comparison of CGS 15943, ZM 241385 and SCH 58261 as antagonists at human adenosine receptors. Naunyn Schmiedebergs Arch Pharmacol 359: 7-10 [PMID:9933143]

272. Ongini E and Fredholm BB. (1996) Pharmacology of adenosine A2A receptors. Trends Pharmacol Sci 17: 364-72 [PMID:8979771]

273. Ozola V, Thorand M, Diekmann M, Qurishi R, Schumacher B, Jacobson KA and Müller CE. (2003) 2-Phenylimidazo[2,1-i]purin-5-ones: structure-activity relationships and characterization of potent and selective inverse agonists at Human A3 adenosine receptors. Bioorg Med Chem 11: 347-56 [PMID:12517430]

274. Palmer TM, Gettys TW and Stiles GL. (1995) Differential interaction with and regulation of multiple G-proteins by the rat A3 adenosine receptor. J Biol Chem 270: 16895-902 [PMID:7622506]

275. Palmer TM, Poucher SM, Jacobson KA and Stiles GL. (1995) 125I-4-(2-[7-amino-2-[2-furyl] $[1,2,4]$ triazolo[2,3-a] $[1,3,5]$ triazin-5-yl-amino]ethyl)phenol, a high affinity antagonist radioligand selective for the A2a adenosine receptor. Mol Pharmacol 48: 970-4 [PMID:8848012]

276. Palmer TM and Stiles GL. (1995) Adenosine receptors. Neuropharmacology 34: 683-94 [PMID:8532135]

277. Peirce SM, Skalak TC, Rieger JM, Macdonald TL and Linden J. (2001) Selective A(2A) adenosine receptor activation reduces skin pressure ulcer formation and inflammation. Am J Physiol Heart Circ Physiol 281: H67-74 [PMID:11406470]

278. Peterfreund RA, MacCollin M, Gusella J and Fink JS. (1996) Characterization and expression of the human A2a adenosine receptor gene. J Neurochem 66: 362-8 [PMID:8522976]

279. Pfeifer CA, Suzuki F and Jackson EK. (1995) Selective A1 adenosine receptor antagonism augments beta-adrenergic-induced renin release in vivo. Am J Physiol 269: F469-79 [PMID:7485531]

280. Pfeiffer M, Kirscht S, Stumm R, Koch T, Wu D, Laugsch M, Schröder H, Höllt V and Schulz S. (2003) Heterodimerization of substance $\mathrm{P}$ and mu-opioid receptors regulates receptor trafficking and resensitization. J Biol Chem 278: 51630-7 [PMID:14532289]

281. Pfister JR, Belardinelli L, Lee G, Lum RT, Milner P, Stanley WC, Linden J, Baker SP and Schreiner G. (1997) Synthesis and biological evaluation of the enantiomers of the potent and 
selective A1-adenosine antagonist 1,3-dipropyl-8-[2-(5,6-epoxynorbonyl)]-xanthine. J Med Chem 40: 1773-8 [PMID:9191953]

282. Pierce KD, Furlong TJ, Selbie LA and Shine J. (1992) Molecular cloning and expression of an adenosine A2b receptor from human brain. Biochem Biophys Res Commun 187: 86-93 [PMID:1325798]

283. Pinna A, Wardas J, Simola N and Morelli M. (2005) New therapies for the treatment of Parkinson's disease: adenosine A2A receptor antagonists. Life Sci 77: 3259-67 [PMID:15979104]

284. Poon A and Sawynok J. (1998) Antinociception by adenosine analogs and inhibitors of adenosine metabolism in an inflammatory thermal hyperalgesia model in the rat. Pain 74: 235-45 [PMID:9520238]

285. Popoli P, Betto P, Reggio R and Ricciarello G. (1995) Adenosine A2A receptor stimulation enhances striatal extracellular glutamate levels in rats. Eur J Pharmacol 287: 215-7 [PMID:8749040]

286. Pretorius J, Malan SF, Castagnoli N, Bergh JJ and Petzer JP. (2008) Dual inhibition of monoamine oxidase $\mathrm{B}$ and antagonism of the adenosine $\mathrm{A}(2 \mathrm{~A})$ receptor by (E,E)-8-(4phenylbutadien-1-yl)caffeine analogues. Bioorg Med Chem 16: 8676-84 [PMID:18723354]

287. Rebola N, Canas PM, Oliveira CR and Cunha RA. (2005) Different synaptic and subsynaptic localization of adenosine A2A receptors in the hippocampus and striatum of the rat. Neuroscience 132: 893-903 [PMID:15857695]

288. Ren H and Stiles GL. (1994) Characterization of the human A1 adenosine receptor gene. Evidence for alternative splicing. J Biol Chem 269: 3104-10 [PMID:8300646]

289. Rice AM, Fain JN and Rivkees SA. (2000) A1 adenosine receptor activation increases adipocyte leptin secretion. Endocrinology 141: 1442-5 [PMID:10746648]

290. Rivkees SA. (1994) Localization and characterization of adenosine receptor expression in rat testis. Endocrinology 135: 2307-13 [PMID:7988413]

291. Rivkees SA, Barbhaiya H and IJzerman AP. (1999) Identification of the adenine binding site of the human A1 adenosine receptor. J Biol Chem 274: 3617-21 [PMID:9920910]

292. Rosin DL, Robeva A, Woodard RL, Guyenet PG and Linden J. (1998) Immunohistochemical localization of adenosine A2A receptors in the rat central nervous system. J Comp Neurol 401: 163-86 [PMID:9822147]

293. Sajjadi FG and Firestein GS. (1993) cDNA cloning and sequence analysis of the human A3 adenosine receptor. Biochim Biophys Acta 1179: 105-7 [PMID:8399349]

294. Sajjadi FG, Takabayashi K, Foster AC, Domingo RC and Firestein GS. (1996) Inhibition of TNFalpha expression by adenosine: role of A3 adenosine receptors. J Immunol 156: 3435-42 [PMID:8617970]

295. Saki M, Tsumuki H, Nonaka H, Shimada J and Ichimura M. (2002) KF26777 (2-(4bromophenyl)-7,8-dihydro-4-propyl-1H-imidazo[2,1-i]purin-5(4H)-one dihydrochloride), a new potent and selective adenosine A3 receptor antagonist. Eur J Pharmacol 444: 133-41 [PMID:12063073]

296. Salehi A, Parandeh F, Fredholm BB, Grapengiesser E and Hellman B. (2009) Absence of adenosine A1 receptors unmasks pulses of insulin release and prolongs those of glucagon and somatostatin. Life Sci 85: 470-6 [PMID:19682463]

297. Salvatore CA, Jacobson MA, Taylor HE, Linden J and Johnson RG. (1993) Molecular cloning and characterization of the human A3 adenosine receptor. Proc Natl Acad Sci USA 90: 10365-9 [PMID:8234299]

298. Salvatore CA, Tilley SL, Latour AM, Fletcher DS, Koller BH and Jacobson MA. (2000) Disruption of the $\mathrm{A}(3)$ adenosine receptor gene in mice and its effect on stimulated inflammatory cells. $J$ Biol Chem 275: 4429-34 [PMID:10660615]

299. Satoh A, Shimosegawa T, Satoh K, Ito H, Kohno Y, Masamune A, Fujita M and Toyota T. (2000) Activation of adenosine A1-receptor pathway induces edema formation in the pancreas of rats. Gastroenterology 119: 829-36 [PMID:10982777]

300. Satoh S, Matsumura H and Hayaishi O. (1998) Involvement of adenosine A2A receptor in sleep promotion. Eur J Pharmacol 351: 155-62 [PMID:9686998]

301. Satoh S, Matsumura H, Koike N, Tokunaga Y, Maeda T and Hayaishi O. (1999) Regiondependent difference in the sleep-promoting potency of an adenosine A2A receptor agonist. Eur J Neurosci 11: 1587-97 [PMID:10215911]

302. Satoh S, Matsumura H, Suzuki F and Hayaishi O. (1996) Promotion of sleep mediated by the A2a-adenosine receptor and possible involvement of this receptor in the sleep induced by prostaglandin D2 in rats. Proc Natl Acad Sci USA 93: 5980-4 [PMID:8650205]

303. Sauer R, Maurinsh J, Reith U, Fülle F, Klotz KN and Müller CE. (2000) Water-soluble phosphate prodrugs of 1-propargyl-8-styrylxanthine derivatives, A(2A)-selective adenosine receptor antagonists. J Med Chem 43: 440-8 [PMID:10669571]

304. Scammell TE, Arrigoni E, Thompson MA, Ronan PJ, Saper CB and Greene RW. (2003) Focal deletion of the adenosine A1 receptor in adult mice using an adeno-associated viral vector. $J$ 
Neurosci 23: 5762-70 [PMID:12843280]

305. Scammell TE, Gerashchenko DY, Mochizuki T, McCarthy MT, Estabrooke IV, Sears CA, Saper CB, Urade Y and Hayaishi O. (2001) An adenosine A2a agonist increases sleep and induces Fos in ventrolateral preoptic neurons. Neuroscience 107: 653-63 [PMID:11720788]

306. Schindler M, Harris CA, Hayes B, Papotti M and Humphrey PP. (2001) Immunohistochemical localization of adenosine A1 receptors in human brain regions. Neurosci Lett 297: 211-5 [PMID:11137765]

307. Schnermann J, Weihprecht H and Briggs JP. (1990) Inhibition of tubuloglomerular feedback during adenosine1 receptor blockade. Am J Physiol 258: F553-61 [PMID:1969237]

308. Schnurr M, Toy T, Shin A, Hartmann G, Rothenfusser S, Soellner J, Davis ID, Cebon J and Maraskovsky E. (2004) Role of adenosine receptors in regulating chemotaxis and cytokine production of plasmacytoid dendritic cells. Blood 103: 1391-7 [PMID:14551144]

309. Scholz KP and Miller RJ. (1992) Inhibition of quantal transmitter release in the absence of calcium influx by a G protein-linked adenosine receptor at hippocampal synapses. Neuron 8: 1139-50 [PMID:1351733]

310. Schulte G and Fredholm BB. (2000) Human adenosine A(1), A(2A), A(2B), and A(3) receptors expressed in Chinese hamster ovary cells all mediate the phosphorylation of extracellularregulated kinase 1/2. Mol Pharmacol 58: 477-82 [PMID:10953039]

311. Schulte G, Robertson B, Fredholm BB, DeLander GE, Shortland P and Molander C. (2003) Distribution of antinociceptive adenosine A1 receptors in the spinal cord dorsal horn, and relationship to primary afferents and neuronal subpopulations. Neuroscience 121: 907-16 [PMID:14580941]

312. Schweda F, Segerer F, Castrop H, Schnermann J and Kurtz A. (2005) Blood pressure-dependent inhibition of Renin secretion requires A1 adenosine receptors. Hypertension 46: 780-6 [PMID:16172432]

313. Segala E, Guo D, Cheng RK, Bortolato A, Deflorian F, Doré AS, Errey JC, Heitman LH, IJzerman AP and Marshall FH et al.. (2016) Controlling the Dissociation of Ligands from the Adenosine A2A Receptor through Modulation of Salt Bridge Strength. J Med Chem 59: 6470-9 [PMID:27312113]

314. Seitz L, Jin L, Leleti M, Ashok D, Jeffrey J, Rieger A, Tiessen RG, Arold G, Tan JBL and Powers JP et al.. (2019) Safety, tolerability, and pharmacology of AB928, a novel dual adenosine receptor antagonist, in a randomized, phase 1 study in healthy volunteers. Invest New Drugs 37: 711-721 [PMID:30569245]

315. Shen HY, Coelho JE, Ohtsuka N, Canas PM, Day YJ, Huang QY, Rebola N, Yu L, Boison D and Cunha RA et al.. (2008) A critical role of the adenosine A2A receptor in extrastriatal neurons in modulating psychomotor activity as revealed by opposite phenotypes of striatum and forebrain A2A receptor knock-outs. J Neurosci 28: 2970-5 [PMID:18354001]

316. Sherbiny FF, Schiedel AC, Maass A and Müller CE. (2009) Homology modelling of the human adenosine A2B receptor based on X-ray structures of bovine rhodopsin, the beta2-adrenergic receptor and the human adenosine A2A receptor. J Comput Aided Mol Des 23: 807-28 [PMID:19757091]

317. Shimada J, Koike N Nonaka H, Shiozaki S, Yanagawa K, Kanda T, Kobayashi H, Ichimura M, Nakamura J and Kase $\mathrm{H}$ et al.. (1997) Adenosine A2A antagonists with potent anti-cataleptic activity. Bioorg Med Chem Lett: 2349-2352

318. Shinkre BA, Kumar TS, Gao ZG, Deflorian F, Jacobson KA and Trenkle WC. (2010) Synthesis and evaluation of 1,2,4-triazolo[1,5-c]pyrimidine derivatives as A2A receptor-selective antagonists. Bioorg Med Chem Lett 20: 5690-4 [PMID:20801028]

319. Shryock JC, Snowdy S, Baraldi PG, Cacciari B, Spalluto G, Monopoli A, Ongini E, Baker SP and Belardinelli L. (1998) A2A-adenosine receptor reserve for coronary vasodilation. Circulation $\mathbf{9 8 :}$ 711-8 [PMID:9715864]

320. Sjölund KF, Sollevi A, Segerdahl M and Lundeberg T. (1997) Intrathecal adenosine analog administration reduces substance $\mathrm{P}$ in cerebrospinal fluid along with behavioral effects that suggest antinociception in rats. Anesth Analg 85: 627-32 [PMID:9296420]

321. Smailagic A, Hakansson H, Jansson A, Michaalsson E, Lal H, Uddin M and Catley M. (2014) Abstract A5742: Impact of A2a receptor activation on inflammation, lung mechanics and a wide panel of mediators in the LPS-induced lung injury in mice Am J Respir Crit Care Med 189: A5742

322. Solinas M, Ferré S, Antoniou K, Quarta D, Justinova Z, Hockemeyer J, Pappas LA, Segal PN, Wertheim C and Müller CE et al.. (2005) Involvement of adenosine A1 receptors in the discriminative-stimulus effects of caffeine in rats. Psychopharmacology (Berl.) 179: 576-86 [PMID:15696333]

323. Stehle JH, Rivkees SA, Lee JJ, Weaver DR, Deeds JD and Reppert SM. (1992) Molecular cloning and expression of the cDNA for a novel A2-adenosine receptor subtype. Mol Endocrinol 6: 38493 [PMID:1584214]

324. Stella L, de Novellis V, Marabese I, Berrino L, Maione S, Filippelli A and Rossi F. (1998) The role of A3 adenosine receptors in central regulation of arterial blood pressure. Br J Pharmacol 
125: 437-40 [PMID:9806324]

325. Stenberg D, Litonius E, Halldner L, Johansson B, Fredholm BB and Porkka-Heiskanen T. (2003) Sleep and its homeostatic regulation in mice lacking the adenosine A1 receptor. J Sleep Res 12: 283-90 [PMID:14633239]

326. Stewart M, Steinig AG, Ma C, Song JP, McKibben B, Castelhano AL and MacLennan SJ. (2004) [3H]OSIP339391, a selective, novel, and high affinity antagonist radioligand for adenosine A2B receptors. Biochem Pharmacol 68: 305-12 [PMID:15194002]

327. Storr M, Thammer J, Dunkel R, Schusdziarra V and Allescher HD. (2002) Modulatory effect of adenosine receptors on the ascending and descending neural reflex responses of rat ileum. $B M C$ Neurosci 3: 21 [PMID:12495441]

328. Sullivan GW, Rieger JM, Scheld WM, Macdonald TL and Linden J. (2001) Cyclic AMP-dependent inhibition of human neutrophil oxidative activity by substituted 2-propynylcyclohexyl adenosine A(2A) receptor agonists. Br J Pharmacol 132: 1017-26 [PMID:11226132]

329. Sun D, Samuelson LC, Yang T, Huang Y, Paliege A, Saunders T, Briggs J and Schnermann J. (2001) Mediation of tubuloglomerular feedback by adenosine: evidence from mice lacking adenosine 1 receptors. Proc Natl Acad Sci USA 98: 9983-8 [PMID:11504952]

330. Sun Y, Wu F, Sun F and Huang P. (2008) Adenosine promotes IL-6 release in airway epithelia. $J$ Immunol 180: 4173-81 [PMID:18322229]

331. Svenningsson P, Le Moine C, Fisone G and Fredholm BB. (1999) Distribution, biochemistry and function of striatal adenosine A2A receptors. Prog Neurobiol 59: 355-96 [PMID:10501634]

332. Talukder MA, Morrison RR, Ledent C and Mustafa SJ. (2003) Endogenous adenosine increases coronary flow by activation of both A2A and A2B receptors in mice. J Cardiovasc Pharmacol 41: 562-70 [PMID:12658057]

333. Thomson S, Bao D, Deng A and Vallon V. (2000) Adenosine formed by 5'-nucleotidase mediates tubuloglomerular feedback. J Clin Invest 106: 289-98 [PMID:10903345]

334. Tilley SL, Tsai M, Williams CM, Wang ZS, Erikson CJ, Galli SJ and Koller BH. (2003) Identification of A3 receptor- and mast cell-dependent and -independent components of adenosine-mediated airway responsiveness in mice. J Immunol 171: 331-7 [PMID:12817015]

335. Tilley SL, Wagoner VA, Salvatore CA, Jacobson MA and Koller BH. (2000) Adenosine and inosine increase cutaneous vasopermeability by activating $\mathrm{A}(3)$ receptors on mast cells. J Clin Invest 105: 361-7 [PMID:10675362]

336. Todde S, Moresco RM, Simonelli P, Baraldi PG, Cacciari B, Spalluto G, Varani K, Monopoli A, Matarrese $M$ and Carpinelli A et al.. (2000) Design, radiosynthesis, and biodistribution of a new potent and selective ligand for in vivo imaging of the adenosine A(2A) receptor system using positron emission tomography. J Med Chem 43: 4359-62 [PMID:11087559]

337. Tosh DK, Deflorian F, Phan K, Gao ZG, Wan TC, Gizewski E, Auchampach JA and Jacobson KA. (2012) Structure-guided design of A(3) adenosine receptor-selective nucleosides: combination of 2-arylethynyl and bicyclo[3.1.0]hexane substitutions. J Med Chem 55: 4847-60 [PMID:22559880]

338. Tosh DK, Rao H, Bitant A, Salmaso V, Mannes P, Lieberman DI, Vaughan KL, Mattison JA, Rothwell AC and Auchampach JA et al.. (2019) Design and in Vivo Characterization of $\mathrm{A}_{1}$ Adenosine Receptor Agonists in the Native Ribose and Conformationally Constrained (N)Methanocarba Series. J Med Chem 62: 1502-1522 [PMID:30605331]

339. Townsend-Nicholson A and Schofield PR. (1994) A threonine residue in the seventh transmembrane domain of the human A1 adenosine receptor mediates specific agonist binding. $J$ Biol Chem 269: 2373-6 [PMID:8300561]

340. Townsend-Nicholson A and Shine J. (1992) Molecular cloning and characterisation of a human brain A1 adenosine receptor cDNA. Brain Res Mol Brain Res 16: 365-70 [PMID:1339301]

341. Tracey WR, Magee WP, Oleynek JJ, Hill RJ, Smith AH, Flynn DM and Knight DR. (2003) Novel N6-substituted adenosine 5'-N-methyluronamides with high selectivity for human adenosine A3 receptors reduce ischemic myocardial injury. Am J Physiol Heart Circ Physiol 285: H2780-7 [PMID:12919933]

342. Turner CP, Seli M, Ment L, Stewart W, Yan H, Johansson B, Fredholm BB, Blackburn M and Rivkees SA. (2003) A1 adenosine receptors mediate hypoxia-induced ventriculomegaly. Proc Natl Acad Sci USA 100: 11718-22 [PMID:12975523]

343. Valant C, May LT, Aurelio L, Chuo CH, White PJ, Baltos JA, Sexton PM, Scammells PJ and Christopoulos A. (2014) Separation of on-target efficacy from adverse effects through rational design of a bitopic adenosine receptor agonist. Proc Natl Acad Sci USA 111: 4614-9 [PMID:24619092]

344. van der Horst E, van der Pijl R, Mulder-Krieger T, Bender A and Ijzerman AP. (2011) Substructure-based virtual screening for adenosine A2A receptor ligands. ChemMedChem $\mathbf{6}$ : 2302-11 [PMID:22021213]

345. van der Klein PA, Kourounakis AP and IJzerman AP. (1999) Allosteric modulation of the adenosine A(1) receptor. Synthesis and biological evaluation of novel 2-amino-3benzoylthiophenes as allosteric enhancers of agonist binding. J Med Chem 42: 3629-35 
[PMID:10479294]

346. van der Wenden EM, Carnielli M, Roelen HC, Lorenzen A, von Frijtag Drabbe Künzel JK and IJzerman AP. (1998) 5'-substituted adenosine analogs as new high-affinity partial agonists for the adenosine A1 receptor. J Med Chem 41: 102-8 [PMID:9438026]

347. van Galen PJ, van Bergen AH, Gallo-Rodriguez C, Melman N, Olah ME, IJzerman AP, Stiles GL and Jacobson KA. (1994) A binding site model and structure-activity relationships for the rat A3 adenosine receptor. Mol Pharmacol 45: 1101-11 [PMID:8022403]

348. van Muijlwijk-Koezen JE, Timmerman H, Link R, van der Goot H and IJzerman AP. (1998) A novel class of adenosine A3 receptor ligands. 1. 3-(2-Pyridinyl)isoquinoline derivatives. J Med Chem 41: 3987-93 [PMID:9767636]

349. van Muijlwijk-Koezen JE, Timmerman H, Link R, van der Goot H and Ijzerman AP. (1998) A novel class of adenosine A3 receptor ligands. 2. Structure affinity profile of a series of isoquinoline and quinazoline compounds. J Med Chem 41: 3994-4000 [PMID:9767637]

350. van Muijlwijk-Koezen JE, Timmerman H, van der Goot H, Menge WM, Frijtag Von Drabbe Künzel J, de Groote M and IJzerman AP. (2000) Isoquinoline and quinazoline urea analogues as antagonists for the human adenosine A(3) receptor. J Med Chem 43: 2227-38 [PMID:10841801]

351. van Rhee AM, Jiang JL, Melman N, Olah ME, Stiles GL and Jacobson KA. (1996) Interaction of 1,4-dihydropyridine and pyridine derivatives with adenosine receptors: selectivity for A3 receptors. J Med Chem 39: 2980-9 [PMID:8709132]

352. van Tilburg EW, Gremmen M, von Frijtag Drabbe Künzel J, de Groote M and IJzerman AP. (2003) 2,8-Disubstituted adenosine derivatives as partial agonists for the adenosine A2A receptor. Bioorg Med Chem 11: 2183-92 [PMID:12713828]

353. van Tilburg EW, von Frijtag Drabbe Kunzel J, de Groote M and IJzerman AP. (2002) 2,5'Disubstituted adenosine derivatives: evaluation of selectivity and efficacy for the adenosine $A(1)$, A(2A), and A(3) receptor. J Med Chem 45: 420-9 [PMID:11784146]

354. van Westen GJ, van den Hoven OO, van der Pijl R, Mulder-Krieger T, de Vries H, Wegner JK, Ijzerman AP, van Vlijmen HW and Bender A. (2012) Identifying novel adenosine receptor ligands by simultaneous proteochemometric modeling of rat and human bioactivity data. J Med Chem 55: 7010-20 [PMID:22827545]

355. Varani K, Gessi S, Dalpiaz A and Borea PA. (1996) Pharmacological and biochemical characterization of purified A2a adenosine receptors in human platelet membranes by [3H]-CGS 21680 binding. Br J Pharmacol 117: 1693-701 [PMID:8732278]

356. Varani K, Gessi S, Merighi S, Vincenzi F, Cattabriga E, Benini A, Klotz KN, Baraldi PG, Tabrizi MA and Lennan SM et al.. (2005) Pharmacological characterization of novel adenosine ligands in recombinant and native human A2B receptors. Biochem Pharmacol 70: 1601-12 [PMID:16219300]

357. Varani K, Merighi S, Gessi S, Klotz KN, Leung E, Baraldi PG, Cacciari B, Romagnoli R, Spalluto G and Borea PA. (2000) [(3)H]MRE 3008F20: a novel antagonist radioligand for the pharmacological and biochemical characterization of human A(3) adenosine receptors. Mol Pharmacol 57: 968-75 [PMID:10779381]

358. Varani K, Portaluppi F, Gessi S, Merighi S, Ongini E, Belardinelli L and Borea PA. (2000) Dose and time effects of caffeine intake on human platelet adenosine $\mathrm{A}(2 \mathrm{~A})$ receptors : functional and biochemical aspects. Circulation 102: 285-9 [PMID:10899090]

359. Varani K, Portaluppi F, Merighi S, Ongini E, Belardinelli L and Borea PA. (1999) Caffeine alters A2A adenosine receptors and their function in human platelets. Circulation 99: 2499-502 [PMID:10330379]

360. Varani K, Vincenzi F, Tosi A, Targa M, Masieri FF, Ongaro A, De Mattei M, Massari L and Borea PA. (2010) Expression and functional role of adenosine receptors in regulating inflammatory responses in human synoviocytes. Br J Pharmacol 160: 101-15 [PMID:20331607]

361. Vidal B, Nueda A, Esteve C, Domenech T, Benito S, Reinoso RF, Pont M, Calbet M, López R and Cadavid MI et al.. (2007) Discovery and characterization of 4'-(2-furyl)-N-pyridin-3-yl-4,5'bipyrimidin-2'-amine (LAS38096), a potent, selective, and efficacious A2B adenosine receptor antagonist. J Med Chem 50: 2732-6 [PMID:17469811]

362. Vitzthum H, Weiss B, Bachleitner W, Krämer BK and Kurtz A. (2004) Gene expression of adenosine receptors along the nephron. Kidney Int 65: 1180-90 [PMID:15086457]

363. Volpini R, Buccioni M, Dal Ben D, Lambertucci C, Lammi C, Marucci G, Ramadori AT, Klotz KN and Cristalli G. (2009) Synthesis and biological evaluation of 2-alkynyl-N6-methyl-5'-Nmethylcarboxamidoadenosine derivatives as potent and highly selective agonists for the human adenosine A3 receptor. J Med Chem 52: 7897-900 [PMID:19839592]

364. Volpini R, Costanzi S, Lambertucci C, Taffi S, Vittori S, Klotz KN and Cristalli G. (2002) N(6)alkyl-2-alkynyl derivatives of adenosine as potent and selective agonists at the human adenosine A(3) receptor and a starting point for searching A(2B) ligands. J Med Chem 45: 3271-9 [PMID:12109910]

365. Voors AA, Bax JJ, Hernandez AF, Wirtz AB, Pap AF, Ferreira AC, Senni M, van der Laan M, Butler J and PANTHEON Investigators. (2019) Safety and efficacy of the partial adenosine A1 receptor agonist neladenoson bialanate in patients with chronic heart failure with reduced 
ejection fraction: a phase IIb, randomized, double-blind, placebo-controlled trial. Eur J Heart Fail 21: 1426-1433 [PMID:31523892]

366. Wan W, Sutherland GR and Geiger JD. (1990) Binding of the adenosine A2 receptor ligand [3H]CGS 21680 to human and rat brain: evidence for multiple affinity sites. J Neurochem $\mathbf{5 5}$ : 1763-71 [PMID:2213023]

367. Wang JH, Short J, Ledent C, Lawrence AJ and van den Buuse M. (2003) Reduced startle habituation and prepulse inhibition in mice lacking the adenosine A2A receptor. Behav Brain Res 143: 201-7 [PMID:12900046]

368. Weiss SM, Benwell K, Cliffe IA, Gillespie RJ, Knight AR, Lerpiniere J, Misra A, Pratt RM, Revell $\mathrm{D}$ and Upton R et al.. (2003) Discovery of nonxanthine adenosine A2A receptor antagonists for the treatment of Parkinson's disease. Neurology 61: S101-6 [PMID:14663021]

369. Weyler S, Fülle F, Diekmann M, Schumacher B, Hinz S, Klotz KN and Müller CE. (2006) Improving potency, selectivity, and water solubility of adenosine A1 receptor antagonists: xanthines modified at position 3 and related pyrimido[1,2,3-cd]purinediones. ChemMedChem 1: 891-902 [PMID:16902942]

370. Willingham SB, Ho PY, Hotson A, Hill C, Piccione EC, Hsieh J, Liu L, Buggy JJ, McCaffery I and Miller RA. (2018) A2AR Antagonism with CPI-444 Induces Antitumor Responses and Augments Efficacy to Anti-PD-(L)1 and Anti-CTLA-4 in Preclinical Models. Cancer Immunol Res 6: 11361149 [PMID:30131376]

371. Wittendorp MC, von Frijtag Drabbe Künzel J, Ijzerman AP, Boddeke HW and Biber K. (2004) The mouse brain adenosine A1 receptor: functional expression and pharmacology. Eur J Pharmacol 487: 73-9 [PMID:15033378]

372. Wu WP, Hao JX, Halldner L, Lövdahl C, DeLander GE, Wiesenfeld-Hallin Z, Fredholm BB and Xu XJ. (2005) Increased nociceptive response in mice lacking the adenosine A1 receptor. Pain 113: 395-404 [PMID:15661449]

373. Wu WP, Hao JX, Halldner-Henriksson L, Xu XJ, Jacobson MA, Wiesenfeld-Hallin Z and Fredholm BB. (2002) Decreased inflammatory pain due to reduced carrageenan-induced inflammation in mice lacking adenosine A3 receptors. Neuroscience 114: 523-7 [PMID:12220556]

374. Xaus J, Valledor AF, Cardó M, Marquès L, Beleta J, Palacios JM and Celada A. (1999) Adenosine inhibits macrophage colony-stimulating factor-dependent proliferation of macrophages through the induction of p27kip-1 expression. J Immunol 163: 4140-9 [PMID:10510349]

375. Xu F, Wu H, Katritch V, Han GW, Jacobson KA, Gao ZG, Cherezov V and Stevens RC. (2011) Structure of an agonist-bound human A2A adenosine receptor. Science 332: 322-7 [PMID:21393508]

376. Yamamoto S, Nakanishi O, Matsui T, Shinohara N, Kinoshita H, Lambert C and Ishikawa T. (2003) Intrathecal adenosine A1 receptor agonist attenuates hyperalgesia without inhibiting spinal glutamate release in the rat. Cell Mol Neurobiol 23: 175-85 [PMID:12735630]

377. Yan L, Burbiel JC, Maass A and Müller CE. (2003) Adenosine receptor agonists: from basic medicinal chemistry to clinical development. Expert Opin Emerg Drugs 8: 537-76 [PMID:14662005]

378. Yang D, Zhang Y, Nguyen HG, Koupenova M, Chauhan AK, Makitalo M, Jones MR, St Hilaire C, Seldin DC and Toselli P et al.. (2006) The A2B adenosine receptor protects against inflammation and excessive vascular adhesion. J Clin Invest 116: 1913-23 [PMID:16823489]

379. Yang JN, Tiselius C, Daré E, Johansson B, Valen G and Fredholm BB. (2007) Sex differences in mouse heart rate and body temperature and in their regulation by adenosine A1 receptors. Acta Physiol (Oxf) 190: 63-75 [PMID:17428234]

380. Yang JN, Wang Y, Garcia-Roves PM, Björnholm M and Fredholm BB. (2010) Adenosine A(3) receptors regulate heart rate, motor activity and body temperature. Acta Physiol (Oxf) 199: 22130 [PMID:20121716]

381. Yang X, van Veldhoven JPD, Offringa J, Kuiper BJ, Lenselink EB, Heitman LH, van der Es D and IJzerman AP. (2019) Development of Covalent Ligands for G Protein-Coupled Receptors: A Case for the Human Adenosine $A_{3}$ Receptor. J Med Chem 62: 3539-3552 [PMID:30869893]

382. Yates L, Clark JH, Martin TJ, James S, Broadley KJ and Kidd EJ. (2006) Radioligand binding and functional responses of ligands for human recombinant adenosine A(3) receptors. Auton Autacoid Pharmacol 26: 191-200 [PMID:16553647]

383. Yu C, Gupta J, Chen JF and Yin HH. (2009) Genetic deletion of A2A adenosine receptors in the striatum selectively impairs habit formation. J Neurosci 29: 15100-3 [PMID:19955361]

384. Zhang N, Yang D, Dong H, Chen Q, Dimitrova DI, Rogers TJ, Sitkovsky M and Oppenheim JJ. (2006) Adenosine A2a receptors induce heterologous desensitization of chemokine receptors. Blood 108: 38-44 [PMID:16522819]

385. Zhao TC and Kukreja RC. (2002) Late preconditioning elicited by activation of adenosine A(3) receptor in heart: role of NF- kappa B, iNOS and mitochondrial K(ATP) channel. J Mol Cell Cardiol 34: 263-77 [PMID:11945020]

386. Zhao Z, Francis C and Ravid K. (1999) Characterization of the mouse A3 adenosine receptor gene: exon/intron organization and promoter activity. Genomics 57: 152-155 [PMID:10191095] 
387. Zhao Z, Makaritsis K, Francis CE, Gavras H and Ravid K. (2000) A role for the A3 adenosine receptor in determining tissue levels of cAMP and blood pressure: studies in knock-out mice. Biochim Biophys Acta 1500: 280-90 [PMID:10699369]

388. Zhao Z, Yaar R, Ladd D, Cataldo LM and Ravid K. (2002) Overexpression of A3 adenosine receptors in smooth, cardiac, and skeletal muscle is lethal to embryos. Microvasc Res 63: 61-9 [PMID:11749073]

389. Zhong H, Belardinelli L, Maa T, Feoktistov I, Biaggioni I and Zeng D. (2004) A(2B) adenosine receptors increase cytokine release by bronchial smooth muscle cells. Am J Respir Cell Mol Biol 30: 118-25 [PMID:12855406]

390. Zhong H, Shlykov SG, Molina JG, Sanborn BM, Jacobson MA, Tilley SL and Blackburn MR. (2003) Activation of murine lung mast cells by the adenosine A3 receptor. J Immunol 171: 33845 [PMID:12817016]

391. Zhou QY, Li C, Olah ME, Johnson RA, Stiles GL and Civelli O. (1992) Molecular cloning and characterization of an adenosine receptor: the A3 adenosine receptor. Proc Natl Acad Sci USA 89: 7432-6 [PMID:1323836]

392. Zhou SJ, Zhu ME, Shu D, Du XP, Song XH, Wang XT, Zheng RY, Cai XH, Chen JF and He JC. (2009) Preferential enhancement of working memory in mice lacking adenosine $A(2 \mathrm{~A})$ receptors. Brain Res 1303: 74-83 [PMID:19785999] 